\title{
Nickel(II) and nickel(0) complexes of bis(diisopropylphosphino)amine: Synthesis, structure, and electrochemical activity
}

Diane A. Dickie, ${ }^{a}$ Brittany E. Chacon, ${ }^{b}$ Alibek Issabekov ${ }^{c}$, Kevin Lam ${ }^{* c}$ and Richard A. Kemp ${ }^{* a, b}$ ${ }^{a}$ Department of Chemistry and Chemical Biology, University of New Mexico, Albuquerque, NM, USA, 87111.

${ }^{b}$ Advanced Materials Laboratory, Sandia National Laboratories, Albuquerque, NM, USA, 87106.

${ }^{c}$ Department of Chemistry, School of Science and Technology, Nazarbayev University, Astana, Kazakhstan, 010000.

Corresponding authors. E-mail: kevin.lam@,nu.edu.kz; rakemp@unm.edu.

\section{ABSTRACT}

In its neutral state, bis(diisopropylphosphino)amine HL reacts in equimolar amounts with the nickel halides $\mathrm{NiCl}_{2} \cdot 6 \mathrm{H}_{2} \mathrm{O}, \mathrm{NiBr}_{2}$, and $\mathrm{NiI}_{2}$ in ethanol solutions to give the air- and moisturestable P,P-chelated complexes $(\mathbf{H L}) \mathrm{NiX}_{2}(\mathrm{X}=\mathrm{Cl}, \mathrm{Br}, \mathrm{I})$. Under similar conditions, complexes of the form $\left[(\mathbf{H L})_{2} \mathrm{Ni}\right] \mathrm{X}_{2}\left(\mathrm{X}=\mathrm{BF}_{4}, \mathrm{NO}_{3}, \mathrm{ClO}_{4}\right)$ were prepared from 2:1 ligand-metal ratios of $\mathrm{Ni}\left(\mathrm{BF}_{4}\right)_{2} \bullet 6 \mathrm{H}_{2} \mathrm{O}, \mathrm{Ni}\left(\mathrm{NO}_{3}\right)_{2} \bullet 6 \mathrm{H}_{2} \mathrm{O}$, or $\mathrm{Ni}\left(\mathrm{ClO}_{4}\right)_{2} \bullet 6 \mathrm{H}_{2} \mathrm{O}$. Deprotonation of the ligand with $\mathrm{NaNH}_{2}$ followed by reaction with $\mathrm{NiI}_{2}$ gives $\mathbf{L}_{2} \mathrm{Ni}$ when performed in $\mathrm{Et}_{2} \mathrm{O}$, but leads to the co-crystal $\mathrm{L}_{2} \mathrm{Ni} \cdot 2\left[\mathrm{NCCHC}(\mathrm{Me}) \mathrm{NH}_{2}\right]$ when the solvent is acetonitrile. In addition to these $\mathrm{Ni}^{2+}$ compounds, the $\mathrm{Ni}^{0}$ complex $(\mathbf{H L}) \mathrm{Ni}$ can be prepared from a toluene solution of $\mathrm{Ni}(\mathrm{cod})_{2}$. Each complex has been characterized by a combination of IR and multi-nuclear NMR spectroscopies, as well as single-crystal X-ray diffraction. Electrochemical studies of the complexes revealed irreversible decomposition of the $(\mathbf{H L}) \mathrm{NiX}_{2}(\mathrm{X}=\mathrm{Cl}, \mathrm{Br}, \mathrm{I})$ series, but electrocatalytic $\mathrm{CO}_{2}$ reduction by the $\left[(\mathbf{H L})_{2} \mathrm{Ni}\right] \mathrm{X}_{2}\left(\mathrm{X}=\mathrm{BF}_{4}, \mathrm{NO}_{3}, \mathrm{ClO}_{4}\right)$ compounds. 


\section{INTRODUCTION}

Nickel complexes in which the metal is bound to at least two phosphorus atoms are a very versatile class of molecules. They have been used as stoichiometric reagents for hydrosilation,[1] to form nickelaoxetanes as models for catalytic oxidation processes,[2] and to make mixed-metal compounds to model heterogeneous clusters[3]. They have been used as active catalysts, pre-catalysts, or catalytic model compounds for photoelectrochemical water splitting,[4] ethylene oligomerization and polymerization,[5] functionalization of unsaturated hydrocarbons,[6] cross-coupling reactions, [7] and other processes.[8] Of most interest to us, they are used for the activation and conversion of $\mathrm{CO}_{2},[9]$ an area of growing concern both academically and industrially.[10]

In many cases, the active nickel species is generated by combining the metal and phosphine ligand in situ, with little or no characterization of the resulting complex. Nevertheless, more than 2300 mononuclear $\mathrm{NiP}_{2}$ complexes have been characterized by single-crystal X-ray diffraction.[11] Of these, approximately 100 contain bidentate ligands with a single-atom bridge between the phosphorus centers. With a few exceptions, the bridging atom is split roughly equally between $\mathrm{N}$ and $\mathrm{C}$. A closer examination of these structures reveals a striking difference between these two groups. While most of the carbon bridges are simple methylene $\left(-\mathrm{CH}_{2}-\right)$ fragments, the vast majority of the nitrogen bridges are tertiary amines, with alkyl, aryl, or other groups as the third substituent. Only four complexes contain an unsubstituted nitrogen atom. Of those four complexes, three are based on the neutral ligands $\operatorname{HN}\left[\mathrm{P}(t-\mathrm{Bu})_{2} \mathrm{PMe}(t-\mathrm{Bu})\right][12]$ or $\mathrm{HN}\left(\mathrm{PPh}_{2}\right)_{2},[13]$, while the fourth uses the latter in its anionic, deprotonated form $\left[\mathrm{N}\left(\mathrm{PPh}_{2}\right)_{2}\right]^{-}$. We 
have previously shown that $\mathrm{Mg},[14] \mathrm{Ca}$ or $\mathrm{Sr},[15]$ or $\mathrm{Zn}[16]$ complexes of this anionic ligand will react with $\mathrm{CO}_{2}$ in rather unexpected ways. When the phenyl groups are replaced by isopropyl groups, we have found that the reactivity is often more straightforward. The anion $\left\{\mathrm{N}\left[\mathrm{P}(i-\mathrm{Pr})_{2}\right]_{2}\right\}^{-}$will chelate main group elements through the phosphorus atoms, and the resulting $\mathrm{Zn}[16], \mathrm{Sn},[17]$ or $\operatorname{In}[18]$ complexes will insert $\mathrm{CO}_{2}$ into the M-P bonds. Each of these complexes, however, is unstable in the presence of moisture, a serious drawback to any future, large-scale operation for $\mathrm{CO}_{2}$ capture and recycle/conversion. We hypothesized that if the ligand were kept in its neutral form $\mathrm{HN}\left[\mathrm{P}(i-\mathrm{Pr})_{2}\right]_{2}$, the resulting complexes would be more likely to tolerate moisture and other protic environments. As well, with an eye towards a possible future capture and conversion process, $\mathrm{Ni}$ is fortunately an earth abundant metal, as are our previouslyused $\mathrm{Zn}$ and Sn metals.

\section{Experimental}

\subsection{General Considerations}

All manipulations were carried out in an argon-filled glovebox or by using standard Schlenk techniques unless otherwise noted. The ligand bis(diisopropylphosphino)amine HL was prepared according to literature procedures.[19] Anhydrous solvents were stored in the glovebox over $4 \AA$ molecular sieves prior to use. ${ }^{1} \mathrm{H}$ and ${ }^{13} \mathrm{C}\left\{{ }^{1} \mathrm{H}\right\}$ spectra were referenced to residual solvent downfield of TMS. ${ }^{31} \mathrm{P}\left\{{ }^{1} \mathrm{H}\right\},{ }^{11} \mathrm{~B}\left\{{ }^{1} \mathrm{H}\right\}$, and ${ }^{19} \mathrm{~F}\left\{{ }^{1} \mathrm{H}\right\}$ spectra were referenced to external $85 \% \mathrm{H}_{3} \mathrm{PO}_{4}, \mathrm{BF}_{3} \cdot \mathrm{Et}_{2} \mathrm{O}$, and $\mathrm{C}_{6} \mathrm{~F}_{6}$, respectively. Due to low solubility, ${ }^{13} \mathrm{C}\left\{{ }^{1} \mathrm{H}\right\}$ NMR was not obtained for most compounds. IR spectra were recorded as mineral oil mulls on $\mathrm{KBr}$ windows. Elemental analyses were performed by ALS Global (Tucson, AZ) or on a Perkin Elmer 2400 Series II CHNS/O Analyzer. Single-crystal X-ray diffraction studies were performed on a Bruker Kappa Apex II CCD diffractometer. Crystals were coated in Paratone-N oil and mounted on a 
MiTeGen MicroLoop ${ }^{\mathrm{TM}}$. The Bruker Apex3 software suite[20] was used for data collection, structure solution and refinement. Crystal data are summarized in Table 1.

Electrochemical measurements were carried out using an Autolab 302N potentiostat interfaced through Nova 2.0 software to a personal computer. Electrochemical measurements were performed using $0.1 \mathrm{M}\left[\mathrm{Bu}_{4} \mathrm{NPF}_{6}\right] / \mathrm{THF}$ electrolyte solutions from solvent that had been purified by passing through an alumina-based purification system. Diamond-polished glassy carbon electrodes of $3 \mathrm{~mm}$ diameter were employed for cyclic voltammetry (CV) scans. CV data were evaluated using standard diagnostic criteria for diffusion control and for chemical and electrochemical reversibility. The experimental reference electrode was a silver wire coated with anodically deposited silver chloride and separated from the working solution by a fine glass frit. The electrochemical potentials in this paper are referenced to ferrocene/ferrocenium couple, as recommended elsewhere.[21] The ferrocene potential was obtained by its addition to the analyte solution[22] at an appropriate time in the experiment.

\subsection{Synthesis of (HL) $\mathrm{NiCl}_{2}(\mathbf{1})$}

$\mathrm{NiCl}_{2} \cdot 6 \mathrm{H}_{2} \mathrm{O}(1.0 \mathrm{mmol})$ was dissolved in $10 \mathrm{~mL}$ EtOH and warmed to $50{ }^{\circ} \mathrm{C}$ in air to get a yellow solution. A colorless solution of $\mathbf{H L}(0.25 \mathrm{~g}, 1.0 \mathrm{mmol})$ in $5 \mathrm{~mL}$ EtOH was then added, and the solution immediately turned bright red. The solution was allowed to cool slowly to room temperature and was then further cooled to $4{ }^{\circ} \mathrm{C}$. After $24 \mathrm{~h}$, the supernatant was decanted from red, X-ray quality single crystals. Yield $=0.23 \mathrm{~g}(61 \%), \mathrm{mp}=>200{ }^{\circ} \mathrm{C}$. IR $\vee 3202(\mathrm{br}, \mathrm{N}-\mathrm{H}) \mathrm{cm}^{-}$ ${ }^{1} .{ }^{1} \mathrm{H}\left\{{ }^{31} \mathrm{P}\right\}$ NMR $\left(300 \mathrm{MHz}, \mathrm{CD}_{2} \mathrm{Cl}_{2}\right): \delta 1.33\left(\mathrm{~d},{ }^{3} \mathrm{~J}_{\mathrm{HH}}=7.2 \mathrm{~Hz}, 12 \mathrm{H}, \mathrm{CH}_{3}\right), 1.57\left(\mathrm{~d},{ }^{3} \mathrm{~J}_{\mathrm{HH}}=7.2\right.$ $\left.\mathrm{Hz}, 12 \mathrm{H}, \mathrm{CH}_{3}\right), 2.41$ (sept, $\left.{ }^{3} \mathrm{~J}_{\mathrm{HH}}=7.2 \mathrm{~Hz}, 4 \mathrm{H}, \mathrm{CH}\right), 3.07$ (s, $\left.1 \mathrm{H}, \mathrm{N} H\right) \mathrm{ppm} .{ }^{31} \mathrm{P}\left\{{ }^{1} \mathrm{H}\right\} \mathrm{NMR}(121$ 
$\left.\mathrm{MHz}, \mathrm{CD}_{2} \mathrm{Cl}_{2}\right): \delta 63.9$ ppm. Anal Calcd. for $\mathrm{C}_{12} \mathrm{H}_{29} \mathrm{Cl}_{2} \mathrm{NNiP}_{2}: \mathrm{C}, 38.04 ; \mathrm{H}, 7.71 ; \mathrm{N}, 3.70$. Found: C, 38.06; H, 8.31; N, 3.71.

2.3 Synthesis of (HL)NiBr 2 (2)

$\mathrm{NiBr}_{2}(0.22 \mathrm{~g}, 1.0 \mathrm{mmol})$ was partially dissolved in $10 \mathrm{~mL}$ EtOH and warmed $50{ }^{\circ} \mathrm{C}$ in air to get a peach-colored suspension. A colorless solution of $\mathbf{H L}(0.25 \mathrm{~g}, 1.0 \mathrm{mmol})$ in $5 \mathrm{~mL}$ EtOH was then added, and the mixture immediately turned bright red. The heterogeneous mixture was held at $50{ }^{\circ} \mathrm{C}$ for two hours, and was then allowed to cool slowly to room temperature. After $24 \mathrm{hrs}$, the supernatant was decanted from the red-orange powder. Yield $=$ $0.32 \mathrm{~g}(68 \%), \mathrm{mp}=>200{ }^{\circ} \mathrm{C}$. IR $v 3186(\mathrm{br}, \mathrm{N}-\mathrm{H}) \mathrm{cm}^{-1} .{ }^{1} \mathrm{H}\left\{{ }^{31} \mathrm{P}\right\} \mathrm{NMR}\left(300 \mathrm{MHz}, \mathrm{CD}_{2} \mathrm{Cl}_{2}\right): \delta$ $1.34\left(\mathrm{~d},{ }^{3} \mathrm{~J}_{\mathrm{HH}}=7 \mathrm{~Hz}, 12 \mathrm{H}, \mathrm{CH}_{3}\right), 1.59\left(\mathrm{~d},{ }^{3} \mathrm{~J}_{\mathrm{HH}}=7 \mathrm{~Hz}, 12 \mathrm{H}, \mathrm{CH}_{3}\right), 2.47\left(\mathrm{sept},{ }^{3} \mathrm{~J}_{\mathrm{HH}}=7 \mathrm{~Hz}, 4 \mathrm{H}\right.$, $\mathrm{CH}), 3.11$ (br s, $1 \mathrm{H}, \mathrm{N} H)$ ppm. ${ }^{31} \mathrm{P}\left\{{ }^{1} \mathrm{H}\right\} \mathrm{NMR}\left(121 \mathrm{MHz}, \mathrm{CD}_{2} \mathrm{Cl}_{2}\right): \delta 71.9 \mathrm{ppm}$. Anal Calcd. for $\mathrm{C}_{12} \mathrm{H}_{29} \mathrm{Br}_{2} \mathrm{NNiP}_{2}$ : C, 30.81; H, 6.25; N, 2.99. Found: C, 30.03; H, 6.43; N, 2.93. X-ray quality single crystals were grown by slow evaporation of the NMR solution.

\subsection{Synthesis of (HL)NiI 2 (3)}

$\mathrm{NiI}_{2}(0.31 \mathrm{~g}, 1.0 \mathrm{mmol})$ was combined with $10 \mathrm{~mL} \mathrm{EtOH}$ and warmed $50{ }^{\circ} \mathrm{C}$ in air. A colorless solution of $\mathbf{H L}(0.25 \mathrm{~g}, 1.0 \mathrm{mmol})$ in $5 \mathrm{~mL}$ EtOH was then added, and the mixture immediately turned dark red. The heterogeneous mixtures was held at $50{ }^{\circ} \mathrm{C}$ for five hours, and was then allowed to cool slowly to room temperature. After $24 \mathrm{hrs}$, the supernatant was decanted from the purple-red powder. Yield $=0.39 \mathrm{~g}(69 \%), \mathrm{mp}=>200{ }^{\circ} \mathrm{C} . \quad \mathrm{IR} \vee 3192(\mathrm{w}, \mathrm{N}-\mathrm{H})$ $\mathrm{cm}^{-1} .{ }^{1} \mathrm{H}\left\{{ }^{31} \mathrm{P}\right\}$ NMR $\left(300 \mathrm{MHz}, \mathrm{CD}_{2} \mathrm{Cl}_{2}\right): \delta 1.34\left(\mathrm{~d},{ }^{3} \mathrm{~J}_{\mathrm{HH}}=7.2 \mathrm{~Hz}, 12 \mathrm{H}, \mathrm{CH}_{3}\right), 1.58\left(\mathrm{~d},{ }^{3} \mathrm{~J}_{\mathrm{HH}}=7.2\right.$ $\mathrm{Hz}, 12 \mathrm{H}, \mathrm{CH}_{3}$ ), $2.52\left(\right.$ sept, $\left.{ }^{3} \mathrm{~J}_{\mathrm{HH}}=7.2 \mathrm{~Hz}, 4 \mathrm{H}, \mathrm{CH}\right), 3.27$ (br s, $\left.1 \mathrm{H}, \mathrm{N} H\right) \mathrm{ppm} .{ }^{31} \mathrm{P}\left\{{ }^{1} \mathrm{H}\right\} \mathrm{NMR}$ $\left(121 \mathrm{MHz}, \mathrm{CD}_{2} \mathrm{Cl}_{2}\right) \delta 84.1 \mathrm{ppm}$. Anal Calcd. for $\mathrm{C}_{12} \mathrm{H}_{29} \mathrm{I}_{2} \mathrm{NNiP}_{2}: \mathrm{C}, 25.65 ; \mathrm{H}, 5.20 ; \mathrm{N}, 2.49$. 
Found: $\mathrm{C}, 25.02 ; \mathrm{H}, 5.40 ; \mathrm{N}, 2.45$. X-ray quality single crystals were grown by slow evaporation of the NMR solution.

\subsection{Synthesis of $\left[(\mathrm{HL})_{2} \mathrm{Ni}\right]\left(\mathrm{ClO}_{4}\right)_{2}(4)$}

$\mathrm{Ni}\left(\mathrm{ClO}_{4}\right)_{2} \cdot 6 \mathrm{H}_{2} \mathrm{O}(0.37 \mathrm{~g}, 1.0 \mathrm{mmol})$ was dissolved in $10 \mathrm{~mL} \mathrm{EtOH}$ and warmed to $50{ }^{\circ} \mathrm{C}$ in air to get a pale green solution. A colorless solution of $\mathbf{H L}(0.50 \mathrm{~g}, 2.0 \mathrm{mmol})$ in $10 \mathrm{~mL}$ EtOH was then added, and solution immediately turned bright yellow. The solution was allowed to cool slowly to room temperature and was then further cooled to $4{ }^{\circ} \mathrm{C}$. After $24 \mathrm{~h}$, the supernatant was decanted from yellow, X-ray quality single crystals. Yield $=0.45 \mathrm{~g}(59 \%), \mathrm{mp}=>200{ }^{\circ} \mathrm{C}$. IR v $3150(\mathrm{br}, \mathrm{N}-\mathrm{H}) \mathrm{cm}^{-1} .{ }^{1} \mathrm{H}\left\{{ }^{31} \mathrm{P}\right\} \operatorname{NMR}\left(300 \mathrm{MHz}, \mathrm{CD}_{2} \mathrm{Cl}_{2}\right): \delta 1.37\left(\mathrm{~d},{ }^{3} \mathrm{~J}_{\mathrm{HH}}=7 \mathrm{~Hz}, 24 \mathrm{H}, \mathrm{CH}_{3}\right)$, $1.46\left(\mathrm{~d},{ }^{3} \mathrm{~J}_{\mathrm{HH}}=7 \mathrm{~Hz}, 24 \mathrm{H}, \mathrm{CH}\right), 2.44\left(\mathrm{sept},{ }^{3} \mathrm{~J}_{\mathrm{HH}}=7 \mathrm{~Hz}, 8 \mathrm{H}, \mathrm{CH}\right), 6.01(\mathrm{~s}, 2 \mathrm{H}, \mathrm{NH}) .{ }^{31} \mathrm{P}\left\{{ }^{1} \mathrm{H}\right\}$ NMR (121 MHz, $\mathrm{CD}_{2} \mathrm{Cl}_{2}$ ): $\delta 70.9$ ppm. Anal Calcd. for $\mathrm{C}_{24} \mathrm{H}_{58} \mathrm{Cl}_{2} \mathrm{~N}_{2} \mathrm{NiO}_{8} \mathrm{P}_{4}$ : C, 38.12; H, 7.73; N, 3.70. Found: C, 37.14; H, 8.03; N, 3.65.

2.6 Synthesis of $\left[(\mathrm{HL})_{2} \mathrm{Ni}\right]\left(\mathrm{NO}_{3}\right)_{2}(\mathbf{5})$

Same as 4, beginning with $\mathrm{Ni}\left(\mathrm{NO}_{3}\right)_{2} \cdot 6 \mathrm{H}_{2} \mathrm{O}(0.29 \mathrm{~g}, 1.0 \mathrm{mmol})$. Yield $=0.48 \mathrm{~g}(70 \%)$, mp $=191-193{ }^{\circ} \mathrm{C} . \mathrm{IR} \vee 2569(\mathrm{~m}, \mathrm{~N}-\mathrm{H}) \mathrm{cm}^{-1} .{ }^{1} \mathrm{H}\left\{{ }^{31} \mathrm{P}\right\} \mathrm{NMR}\left(300 \mathrm{MHz}, \mathrm{CD}_{2} \mathrm{Cl}_{2}\right): \delta 1.35\left(\mathrm{~d},{ }^{3} \mathrm{~J}_{\mathrm{HH}}=7\right.$ $\left.\mathrm{Hz}, 24 \mathrm{H}, \mathrm{CH}_{3}\right), 1.46\left(\mathrm{~d},{ }^{3} \mathrm{~J}_{\mathrm{HH}}=7 \mathrm{~Hz}, 24 \mathrm{H}, \mathrm{CH}_{3}\right), 2.43\left(\mathrm{sept},{ }^{3} \mathrm{~J}_{\mathrm{HH}}=7 \mathrm{~Hz}, 8 \mathrm{H}, \mathrm{CH}\right), 8.36(\mathrm{~s}, 2 \mathrm{H}$, $\mathrm{N} H)$ ppm. ${ }^{31} \mathrm{P}\left\{{ }^{1} \mathrm{H}\right\}$ NMR (121 MHz, $\left.\mathrm{CD}_{2} \mathrm{Cl}_{2}\right): \delta 67.4 \mathrm{ppm}$. Anal Calcd. for $\mathrm{C}_{24} \mathrm{H}_{58} \mathrm{~N}_{4} \mathrm{NiO}_{6} \mathrm{P}_{4}: \mathrm{C}$, 42.31; H, 8.58; N, 8.22. Found: C, 42.29; H, 8.89; N, 8.20.

2.7 Synthesis of $\left[(\mathrm{HL})_{2} \mathrm{Ni}\right]\left(\mathrm{BF}_{4}\right)_{2}(\mathbf{6})$

Same as 4, beginning with $\mathrm{Ni}\left(\mathrm{BF}_{4}\right)_{2} \cdot 6 \mathrm{H}_{2} \mathrm{O}(0.34 \mathrm{~g}, 1.0 \mathrm{mmol})$. Yield $=0.34 \mathrm{~g}(47 \%), \mathrm{mp}$ $=>200{ }^{\circ} \mathrm{C} . \mathrm{IR} \vee 3245(\mathrm{~s}, \mathrm{~N}-\mathrm{H}) \mathrm{cm}^{-1} \cdot{ }^{1} \mathrm{H}\left\{{ }^{31} \mathrm{P}\right\} \operatorname{NMR}\left(300 \mathrm{MHz}, \mathrm{C}_{6} \mathrm{D}_{6}\right): \delta 1.36\left(\mathrm{~d},{ }^{3} \mathrm{~J}_{\mathrm{HH}}=7 \mathrm{~Hz}\right.$, 
$\left.24 \mathrm{H}, \mathrm{CH}_{3}\right), 1.47\left(\mathrm{~d},{ }^{3} \mathrm{~J}_{\mathrm{HH}}=7 \mathrm{~Hz}, 24 \mathrm{H}, \mathrm{CH}_{3}\right), 2.43\left(\mathrm{sept},{ }^{3} \mathrm{~J}_{\mathrm{HH}}=7 \mathrm{~Hz}, 8 \mathrm{H}, \mathrm{CH}\right), 5.75(\mathrm{~s}, 2 \mathrm{H}, \mathrm{NH})$.

${ }^{31} \mathrm{P}\left\{{ }^{1} \mathrm{H}\right\}$ NMR (121 MHz, $\left.\mathrm{CD}_{2} \mathrm{Cl}_{2}\right): \delta 70.7$ ppm. ${ }^{19} \mathrm{~F}\left\{{ }^{1} \mathrm{H}\right\}$ NMR $\left(282 \mathrm{MHz}, \mathrm{CD}_{2} \mathrm{Cl}_{2}\right) \delta-149.9$ ppm. ${ }^{11} \mathrm{~B}\left\{{ }^{1} \mathrm{H}\right\}$ NMR $\left(96 \mathrm{MHz}, \mathrm{CD}_{2} \mathrm{Cl}_{2}\right) \delta 0.90$ ppm. Anal Calcd. for $\mathrm{C}_{24} \mathrm{H}_{58} \mathrm{~B}_{2} \mathrm{~F}_{8} \mathrm{~N}_{2} \mathrm{NiP}_{4}: \mathrm{C}$, 39.44; H, 8.00; N, 3.83. Found: C, 39.60; H, 8.22; N, 3.79.

\subsection{Synthesis of $\mathrm{L}_{2} \mathrm{Ni}(7)$}

$\mathrm{NaNH}_{2}(0.08 \mathrm{~g}, 2.0 \mathrm{mmol})$ was added to a colorless solution of $\mathbf{H L}(0.50 \mathrm{~g}, 2.0 \mathrm{mmol})$ in $15 \mathrm{~mL}$ anhydrous $\mathrm{Et}_{2} \mathrm{O}$. The mixture was allowed to stir at $\mathrm{rt}$ for $1.5 \mathrm{~h}$, and then $\mathrm{NiI}_{2}(0.31 \mathrm{~g}, 1.0$ mmol) was added. After stirring for $24 \mathrm{~h}$ at $\mathrm{rt}, \mathrm{NaI}$ was removed by filtration and the volume of the orange solution was reduced under vacuum to ca. $4 \mathrm{~mL}$. Upon cooling to $-25{ }^{\circ} \mathrm{C}$, orange crystals were isolated. Yield $=0.47 \mathrm{~g}(85 \%), \mathrm{mp}=\operatorname{dec}>145{ }^{\circ} \mathrm{C} .{ }^{1} \mathrm{H}\left\{{ }^{31} \mathrm{P}\right\}$ NMR $(300 \mathrm{MHz}$, $\left.\mathrm{C}_{6} \mathrm{D}_{6}\right): \delta 1.15\left(\mathrm{~d},{ }^{3} \mathrm{~J}_{\mathrm{HH}}=7 \mathrm{~Hz}, 24 \mathrm{H}, \mathrm{CH} \mathrm{H}_{3}\right), 1.41\left(\mathrm{~d},{ }^{3} \mathrm{~J}_{\mathrm{HH}}=7 \mathrm{~Hz}, 24 \mathrm{H}, \mathrm{CH}\right), 1.88\left(\mathrm{sept},{ }^{3} \mathrm{~J}_{\mathrm{HH}}=7\right.$ $\mathrm{Hz}, 8 \mathrm{H}, \mathrm{CH}) \mathrm{ppm} .{ }^{13} \mathrm{C}\left\{{ }^{1} \mathrm{H}\right\} \mathrm{NMR}\left(75 \mathrm{MHz}, \mathrm{C}_{6} \mathrm{D}_{6}\right) \delta 16.7\left(\mathrm{~s}, \mathrm{CH}_{3}\right), 19.0\left(\mathrm{~s}, \mathrm{CH}_{3}\right), 30.9$ (vt, $\left.\mathrm{CH}\right)$ ppm. ${ }^{31} \mathrm{P}\left\{{ }^{1} \mathrm{H}\right\}$ NMR $\left(121 \mathrm{MHz}, \mathrm{C}_{6} \mathrm{D}_{6}\right) \delta 24.3 \mathrm{ppm}$. Anal Calcd. for $\mathrm{C}_{24} \mathrm{H}_{56} \mathrm{~N}_{2} \mathrm{NiP}_{4}$ : C, 51.91; $\mathrm{H}$, 10.17; N, 5.04. Found: C, 52.64; H, 10.62, N, 5.28.

\subsection{Synthesis of $\mathrm{L}_{2} \mathrm{Ni} \cdot 2\left[\mathrm{NCCHC}(\mathrm{Me}) \mathrm{NH}_{2}\right](7 \boldsymbol{a})$}

$\mathrm{NaNH}_{2}(0.08 \mathrm{~g}, 2.0 \mathrm{mmol})$ was added to a colorless solution of $\mathbf{H L}(0.50 \mathrm{~g}, 2.0 \mathrm{mmol})$ in $15 \mathrm{~mL}$ anhydrous $\mathrm{MeCN}$. The mixture was allowed to stir at $\mathrm{rt}$ for $1 \mathrm{~h}$, and then $\mathrm{NiI}_{2}(0.31 \mathrm{~g}, 1.0$ mmol) was added. Over the course of $3.5 \mathrm{~h}$, an orange solution with a yellow-orange ppt formed. Volatiles were removed under vacuum, and the residue was suspended in $\mathrm{CH}_{2} \mathrm{Cl}_{2}$. Insoluble $\mathrm{NaI}_{2}$ was separated by filtration, and then the solvent was removed under vacuum to give a yellow-orange powder. Yield $=0.56 \mathrm{~g}(78 \%), \mathrm{mp}=93-94{ }^{\circ} \mathrm{C} .{ }^{1} \mathrm{H}\left\{{ }^{31} \mathrm{P}\right\}$ NMR $(300 \mathrm{MHz}$, $\left.\mathrm{CD}_{2} \mathrm{Cl}_{2}\right): \delta 1.13\left(\mathrm{~d},{ }^{3} \mathrm{~J}_{\mathrm{HH}}=7 \mathrm{~Hz}, 24 \mathrm{H}, \mathrm{CH}_{3}\right), 1.38\left(\mathrm{~d},{ }^{3} \mathrm{~J}_{\mathrm{HH}}=7 \mathrm{~Hz}, 24 \mathrm{H}, \mathrm{CH}_{3}\right), 1.94\left(\mathrm{sept},{ }^{3} \mathrm{~J}_{\mathrm{HH}}=7\right.$ 
$\mathrm{Hz}, 8 \mathrm{H}, \mathrm{CH}), 2.09$ (s, 6H, $\mathrm{CCH}$ ) $, 3.77\left(\mathrm{~s}, 4 \mathrm{H}, \mathrm{NH} H_{2}\right), 4.09$ (s, 2H, $\left.\mathrm{CCH}\right) \mathrm{ppm} .{ }^{13} \mathrm{C}\left\{{ }^{1} \mathrm{H}\right\} \mathrm{NMR}(75$ $\left.\mathrm{MHz}, \mathrm{CD}_{2} \mathrm{Cl}_{2}\right) \delta 16.9\left(\mathrm{~s}, \mathrm{CH}_{3}\right), 19.3\left(\mathrm{~s}, \mathrm{CH}_{3}\right), 19.9\left(\mathrm{~s}, \mathrm{CCH}_{3}\right), 20.4\left(\mathrm{~s}, \mathrm{CCH}_{3}\right), 31.0$ (vt, $\left.\mathrm{PCH}\right)$, $62.0(\mathrm{~s}, \mathrm{CH}), 63.7(\mathrm{~s}, \mathrm{CH}), 119.9(\mathrm{~s}, \mathrm{CN}), 122.0(\mathrm{~s}, \mathrm{CN}), 161.9\left(\mathrm{~s}, C_{\mathrm{CH}}\right), 162.4\left(\mathrm{~s}, C_{\mathrm{CH}}\right) \mathrm{ppm}$. ${ }^{31} \mathrm{P}\left\{{ }^{1} \mathrm{H}\right\} \quad \mathrm{NMR}(121 \mathrm{MHz}) \delta 24.9 \mathrm{ppm}\left(\mathrm{C}_{6} \mathrm{D}_{6}\right) ; 29.1 \mathrm{ppm}\left(\mathrm{CD}_{2} \mathrm{Cl}_{2}\right)$. Anal Calcd. for $\mathrm{C}_{32} \mathrm{H}_{68} \mathrm{~N}_{6} \mathrm{NiP}_{4}: \mathrm{C}, 53.42 ; \mathrm{H}, 9.53 ; \mathrm{N}, 11.68$. Found: $\mathrm{C}, 53.42 ; \mathrm{H}, 9.79 ; \mathrm{N}, 11.82$. X-ray quality single crystals were grown from a concentrated $\mathrm{CH}_{2} \mathrm{Cl}_{2}$ solution.

2.10 Synthesis of $(\mathrm{HL})_{2} \mathrm{Ni}(\boldsymbol{8})$

$\mathrm{Ni}(\operatorname{cod})_{2}(0.28 \mathrm{~g}, 1.0 \mathrm{mmol})$ was dissolved in $10 \mathrm{~mL}$ toluene to give a yellow solution. HL $(0.50 \mathrm{~g}, 2.0 \mathrm{mmol})$ was added and the solution was allowed to stir at $\mathrm{rt}$ for $2 \mathrm{~h}$. Volatiles were removed under vacuum and the residue was dissolved in $1 \mathrm{~mL}$ pentane and cooled to -25 ${ }^{\circ} \mathrm{C}$. After $24 \mathrm{hrs}$, the dark supernatant was decanted from yellow block-like crystals. Yield $=$ $0.31 \mathrm{~g}(56 \%), \mathrm{mp}=\operatorname{dec}>175{ }^{\circ} \mathrm{C} .{ }^{1} \mathrm{H}\left\{{ }^{31} \mathrm{P}\right\} \operatorname{NMR}\left(300 \mathrm{MHz}, \mathrm{C}_{6} \mathrm{D}_{6}\right): \delta 1.21\left(\mathrm{~d},{ }^{3} \mathrm{~J}_{\mathrm{HH}}=7.2 \mathrm{~Hz}\right.$, $\left.12 \mathrm{H}, \mathrm{CH}_{3}\right), 1.23\left(\mathrm{~d},{ }^{3} \mathrm{~J}_{\mathrm{HH}}=7.2 \mathrm{~Hz}, 12 \mathrm{H}, \mathrm{CH}_{3}\right), 1.72(\mathrm{~s}, 1 \mathrm{H}, \mathrm{NH}), 1.90\left(\mathrm{sept},{ }^{3} \mathrm{~J}_{\mathrm{HH}}=7.2 \mathrm{~Hz}, 4 \mathrm{H}\right.$, CH) ppm. ${ }^{13} \mathrm{C}\left\{{ }^{1} \mathrm{H}\right\}$ NMR $\left(75 \mathrm{MHz}, \mathrm{C}_{6} \mathrm{D}_{6}\right) \delta 18.4\left(\mathrm{~s}, \mathrm{CH}_{3}\right), 19.1\left(\mathrm{~s}, \mathrm{CH}_{3}\right), 29.2$ (vt, $\left.\mathrm{CH}\right) \mathrm{ppm}$. ${ }^{31} \mathrm{P}\left\{{ }^{1} \mathrm{H}\right\}$ NMR (121 MHz, $\left.\mathrm{C}_{6} \mathrm{D}_{6}\right) \delta 97.9 \mathrm{ppm}$. IR (Nujol mull) $v 3323(\mathrm{NH}) \mathrm{cm}^{-1}$. Anal Calcd. for $\mathrm{C}_{24} \mathrm{H}_{58} \mathrm{~N}_{2} \mathrm{NiP}_{4}$ : C, 51.72; H, 10.49; N, 5.03. Found: C, 52.02; H, 10.56; N, 4.91. 
Table 1. Crystallographic data for compounds 1-8.

\begin{tabular}{|c|c|c|c|c|c|c|c|c|c|c|c|c|c|c|c|}
\hline$\infty$ & 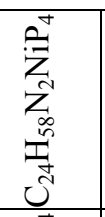 & $\begin{array}{l}\vec{m} \\
\stackrel{i}{n} \\
i n\end{array}$ & $\overline{a^{\prime}}$ & 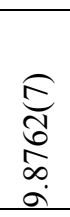 & 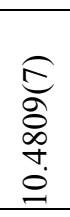 & 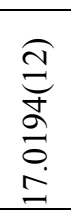 & $\begin{array}{l}\widehat{\mathbb{N}} \\
\infty \\
\infty \\
\infty \\
\infty \\
\end{array}$ & 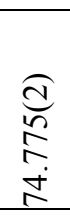 & $\begin{array}{l}\widehat{d} \\
\infty \\
\infty \\
\infty \\
\dot{d} \\
\dot{d}\end{array}$ & 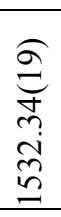 & $\sim$ & 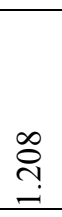 & $\begin{array}{c}0 \\
\swarrow \\
\infty \\
0 \\
0\end{array}$ & $\begin{array}{l}\text { ते } \\
\text { ठे. } \\
\text { : }\end{array}$ & $\begin{array}{l}\text { 莳 } \\
\text { d. } \\
0\end{array}$ \\
\hline$\approx$ & 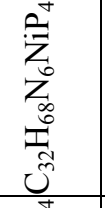 & $\begin{array}{l}\vec{n} \\
\stackrel{2}{n}\end{array}$ & 范 & $\begin{array}{l}\underset{\mathbb{N}}{\mathbb{N}} \\
\Xi \\
\Xi \\
\exists\end{array}$ & $\begin{array}{l}\widehat{\Xi} \\
\underset{N}{D} \\
\infty \\
\infty \\
\infty \\
-\end{array}$ & $\begin{array}{l}\widehat{\mathbb{d}} \\
\stackrel{n}{n} \\
\infty \\
\infty \\
\infty\end{array}$ & & & & 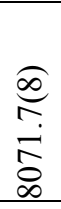 & $\infty$ & $\underset{\infty}{ \pm}$ & $\begin{array}{l}\infty \\
: \\
0 \\
0 \\
0\end{array}$ & $\begin{array}{l}\stackrel{m}{t} \\
\stackrel{0}{0}\end{array}$ & $\begin{array}{l}0 \\
\text { I. } \\
0 \\
0 \\
0\end{array}$ \\
\hline$r$ & 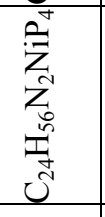 & 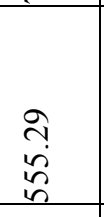 & 范 & 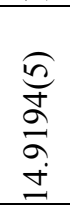 & $\begin{array}{l}\widehat{O} \\
\stackrel{D}{J} \\
\infty \\
\stackrel{0}{=} \\
=\end{array}$ & 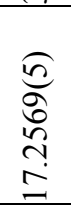 & & & & 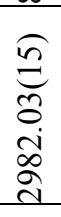 & $\theta$ & 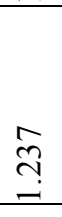 & $\begin{array}{c}\infty \\
\infty \\
\infty \\
0 \\
0\end{array}$ & $\begin{array}{l}\text { to } \\
\text { ते } \\
0\end{array}$ & $\begin{array}{l}\text { ते } \\
\stackrel{0}{\circ}\end{array}$ \\
\hline 6 & 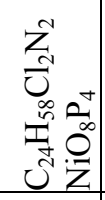 & $\begin{array}{l}\vec{त} \\
\stackrel{n}{n} \\
\end{array}$ & $\frac{\tilde{Z}}{2}$ & $\begin{array}{l}\hat{\sigma} \\
\stackrel{0}{m} \\
\frac{0}{\infty} \\
\dot{I}\end{array}$ & $\begin{array}{l}\widehat{\sigma} \\
\infty \\
\infty \\
\infty \\
\stackrel{\infty}{=} \\
\end{array}$ & 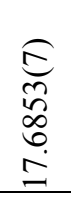 & & & & 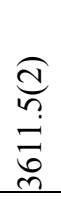 & $\theta$ & बे & 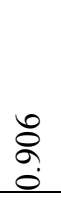 & $\begin{array}{l}\text { 等 } \\
\stackrel{0}{0}\end{array}$ & $\begin{array}{l}\frac{n}{0} \\
0 \\
0\end{array}$ \\
\hline in & 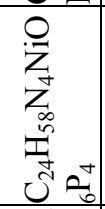 & 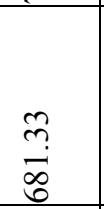 & 苑 & 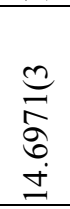 & 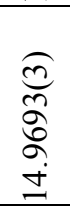 & 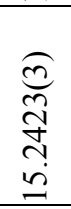 & & & & 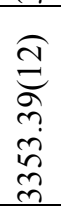 & $\theta$ & 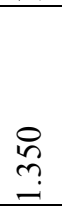 & $\begin{array}{l}\overrightarrow{\vec{D}} \\
0 \\
0\end{array}$ & 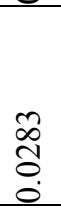 & $\begin{array}{l}8 \\
\stackrel{8}{0} \\
\vdots \\
0\end{array}$ \\
\hline+ & 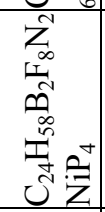 & 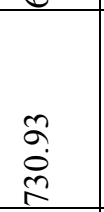 & 范 & 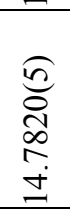 & 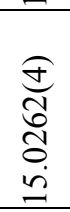 & 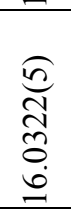 & & & & 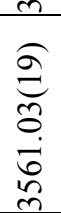 & $\theta$ & 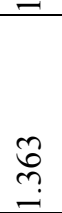 & $\begin{array}{l}\infty \\
\infty \\
0 \\
0 \\
0\end{array}$ & 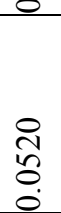 & $\begin{array}{l}\text { चे } \\
\text { m. }\end{array}$ \\
\hline$m$ & 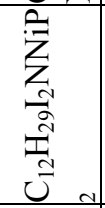 & $\begin{array}{l}\vec{\infty} \\
\vec{D} \\
i\end{array}$ & $\begin{array}{l}\Sigma \\
\Sigma\end{array}$ & \begin{tabular}{l}
$\widehat{\mathbb{d}}$ \\
\multirow{\infty}{\infty}{} \\
$\stackrel{+}{+}$ \\
$\infty$ \\
$\infty$
\end{tabular} & 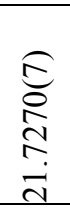 & $\begin{array}{l}\hat{0} \\
\infty \\
0 \\
\hat{0} \\
0 \\
0\end{array}$ & & $\begin{array}{l}\widehat{\mathbb{a}} \\
\widehat{n} \\
\hat{i} \\
\alpha\end{array}$ & & 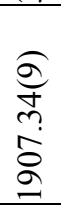 & $\theta$ & ڤ̆ & 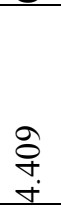 & 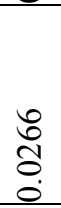 & $\begin{array}{l}\text { 悉 } \\
\stackrel{0}{0} \\
\dot{0}\end{array}$ \\
\hline$N$ & 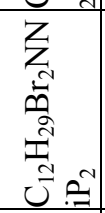 & 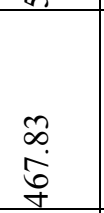 & $\frac{\ddot{\Sigma}}{\Sigma}$ & 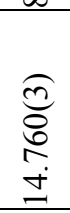 & 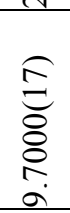 & 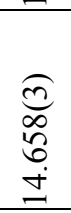 & & $\begin{array}{l}\widehat{a} \\
\stackrel{0}{0} \\
\stackrel{0}{0}\end{array}$ & & 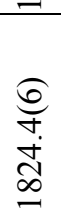 & $\theta$ & 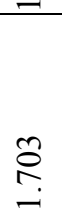 & $\begin{array}{l}\text { ô } \\
\text { ب. }\end{array}$ & $\begin{array}{l}\text { D. } \\
0 \\
0 \\
0 \\
0\end{array}$ & $\begin{array}{l}m \\
\overrightarrow{0} \\
\stackrel{0}{0}\end{array}$ \\
\hline- & 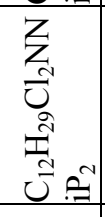 & $\begin{array}{l}\vec{a} \\
\infty \\
\infty \\
\infty\end{array}$ & $\stackrel{u}{\Sigma}$ & 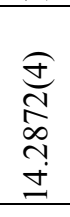 & 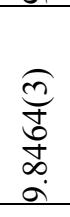 & 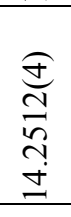 & & 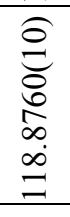 & & 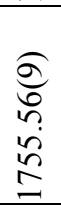 & $\theta$ & 冚 & 点 & 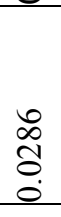 & $\begin{array}{l}0 \\
\infty \\
o \\
o \\
0 \\
0\end{array}$ \\
\hline & 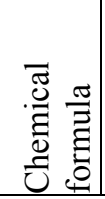 & 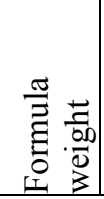 & 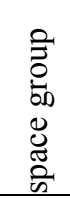 & $\underset{\mathrm{d}}{\mathrm{d}}$ & $\sqrt{0}$ & 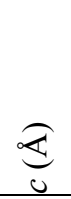 & $\begin{array}{l}\sigma \\
\mho \\
\mho\end{array}$ & $\underset{Q}{0}$ & $\mathfrak{g}$ & 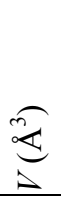 & $v$ & 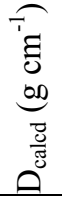 & 唇 & $\begin{array}{l}\stackrel{\vec{b}}{\hat{N}} \\
\underset{\Omega}{\approx}\end{array}$ & 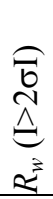 \\
\hline
\end{tabular}




\section{RESULTS AND DISCUSSION}

3.1 Synthesis and structure

To the best of our knowledge, there is only one previous example in which $\mathrm{HN}\left[\mathrm{P}(i-\mathrm{Pr})_{2}\right]_{2}$

(HL) has been directly used as a neutral ligand rather than as an anion. In that case, HL coordinates in a monodentate manner to $\mathrm{B}\left(\mathrm{C}_{6} \mathrm{~F}_{5}\right)_{3}$ through one of its $\mathrm{P}$ atoms and the amine $\mathrm{H}$ atom shifts to the other P.[23] In addition, a Pt complex of HL is claimed in the patent literature,[24] and Woollins and co-workers have reported the low-yield formation of a ruthenium complex containing $\mathbf{H L}$, but in that case it formed via an in situ reduction of the disulfide $\mathrm{HN}\left[\mathrm{P}(=\mathrm{S})(i-\mathrm{Pr})_{2}\right]_{2}$ rather than directly from $\mathbf{H L}$.[25]

The nickel(II) halides $\mathrm{NiCl}_{2}, \mathrm{NiBr}_{2}$ and $\mathrm{NiI}_{2}$ react with $\mathrm{HN}\left[\mathrm{P}(i-\mathrm{Pr})_{2}\right]_{2}(\mathbf{H L})$ in warm ethanol to give complexes with the general formula $(\mathrm{HL}) \mathrm{NiX}$. These red complexes $\mathbf{1}(\mathrm{X}=\mathrm{Cl})$, $2(\mathrm{X}=\mathrm{Br})$, and $\mathbf{3}(\mathrm{X}=\mathrm{I})$ can be handled and stored in air and do not appear to be sensitive to water. In fact, while 1 was initially prepared from anhydrous $\mathrm{NiCl}_{2}$, there was found to be no advantage to using that starting material over the much less expensive and more soluble $\mathrm{NiCl}_{2} \cdot 6 \mathrm{H}_{2} \mathrm{O}$, and so the hexahydrate was used for all subsequent preparations (Scheme 1). Once formed, the complexes 1-3 were found to have relatively poor solubilities in most solvents and as such we were unable to obtain solution-phase ${ }^{13} \mathrm{C}\left\{{ }^{1} \mathrm{H}\right\}$ NMR data, but the ${ }^{1} \mathrm{H}\left\{{ }^{31} \mathrm{P}\right\}$ and ${ }^{31} \mathrm{P}\left\{{ }^{1} \mathrm{H}\right\}$

spectra were recorded in $\mathrm{CD}_{2} \mathrm{Cl}_{2}$. The ${ }^{1} \mathrm{H}\left\{{ }^{31} \mathrm{P}\right\}$ spectra were shifted significantly downfield relative to the free ligand with the $\mathrm{CH}$ septet appearing at 2.41, 2.47 and $2.52 \mathrm{ppm}$ for $\mathbf{1 , 2}$ and $\mathbf{3}$, respectively, and the pair of $\mathrm{CH}_{3}$ doublets at $1.33 / 1.57,1.34 / 1.59$, and $1.34 / 1.58 \mathrm{ppm}$. The $\mathrm{NH}$ proton was observed as a broad singlet at $3.07,3.11$ and $3.27 \mathrm{ppm}$ for the three complexes, and the corresponding N-H IR stretches were found at 3202,3186 and $3192 \mathrm{~cm}^{-1}$. In contrast to the similar chemical shifts of the ${ }^{1} \mathrm{H}$ NMR signals, the ${ }^{31} \mathrm{P}\left\{{ }^{1} \mathrm{H}\right\}$ spectra of $\mathbf{1 - 3}$ were more varied. The 
chloride derivate 1 appeared at $63.9 \mathrm{ppm}$, upfield from the free ligand at $69.1 \mathrm{ppm}$. The bromide 2 and iodide $\mathbf{3}$, however, were shifted downfield, to 71.9 and 84.1, respectively.
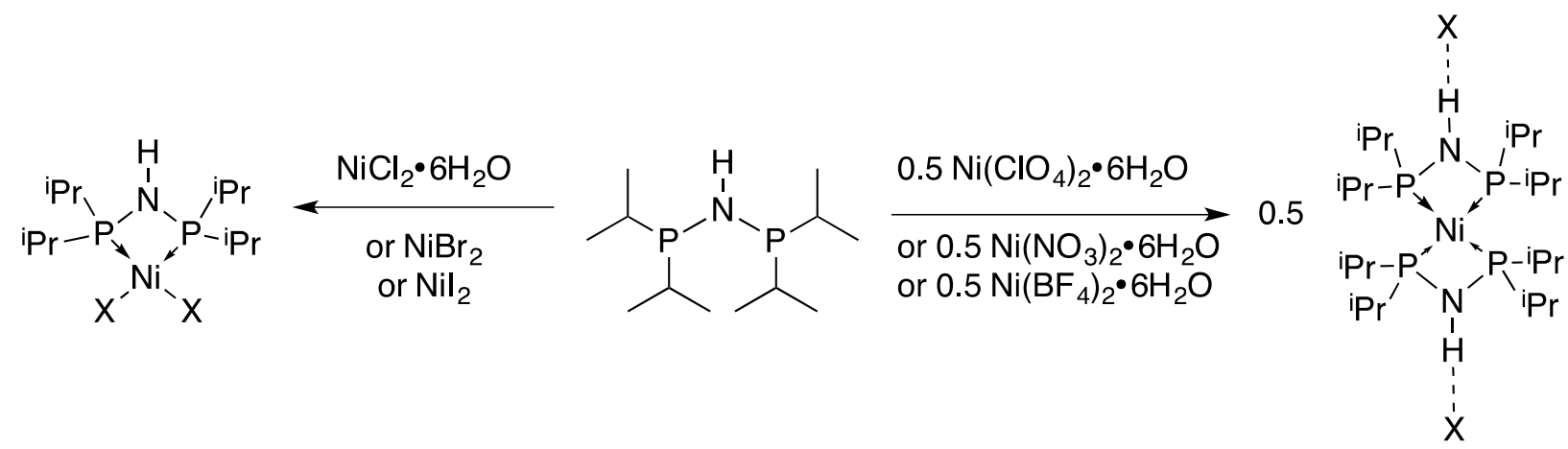

$$
\begin{aligned}
& 1 X=\mathrm{Cl} \\
& 2 X=\mathrm{Br} \\
& 3 X=I
\end{aligned}
$$

$$
\begin{aligned}
& 4 \mathrm{X}=\mathrm{BF}_{4} \\
& 5 \mathrm{X}=\mathrm{NO}_{3} \\
& 6 \mathrm{X}=\mathrm{ClO}_{4}
\end{aligned}
$$

Scheme 1. Synthesis of nickel complexes (HL)NiX 1 1-3 and $\left[(\mathrm{HL})_{2} \mathrm{Ni}\right] \mathrm{X}_{2}$ 4-6.

The spectroscopic data strongly indicated that $\mathrm{HL}$ binds to the nickel halides as a P,Pchelating ligand with the $\mathrm{NH}$ bond intact, in contrast to the monodentate coordination with $\mathrm{NH} / \mathrm{PH}$ tautomerization seen upon reaction with $\mathrm{B}\left(\mathrm{C}_{6} \mathrm{~F}_{5}\right)_{3} \cdot[23]$ To confirm the exact nature of the complexes 1-3, they were examined by single crystal X-ray diffraction. Suitable crystals of $\mathbf{1}$ were obtained directly from the reaction mixture upon cooling, while single crystals of $\mathbf{2}$ and $\mathbf{3}$ were grown from slow evaporation of the NMR solutions.

Each of the structure solutions of $\mathbf{1 - 3}$ revealed a distorted square planar nickel center, bound to two halide atoms and chelated by the phosphorus atoms from a single $\mathbf{H L}$ ligand (Fig. 1). Selected bond lengths and angles are summarized in Table 2. The NH acts as a hydrogen bond donor to one halide in a neighboring molecule, giving rise to infinite 1-D chains in the solid state. The nitrogen atom of the ligand is bent slightly out of the $\mathrm{NiP}_{2}$ plane by $0.146(2), 0.128(4)$, and 0.184(3) A for 1-3, respectively. In an ideal square planar coordination environment, the P 
and $\mathrm{X}$ atoms would be co-planar, but in 1-3 the $\mathrm{NiP}_{2}$ and $\mathrm{NiX}_{2}$ planes were twisted relative to one another by $8.386(4), 7.521(7)$, and $15.158(4){ }^{\circ}$, respectively. The Ni-P bond lengths are unremarkable compared to previously reported nickel dihalides containing a P,P-chelating Nbridged ligand, whose mean value in the Cambridge Structural Database[11] is $2.123 \AA$ (range 2.101-2.161 $\AA$ ). The N-P bond lengths, however, fall at the short end of the range of 1.684$1.745 \AA$ (mean $1.700 \AA)$ for known structures.
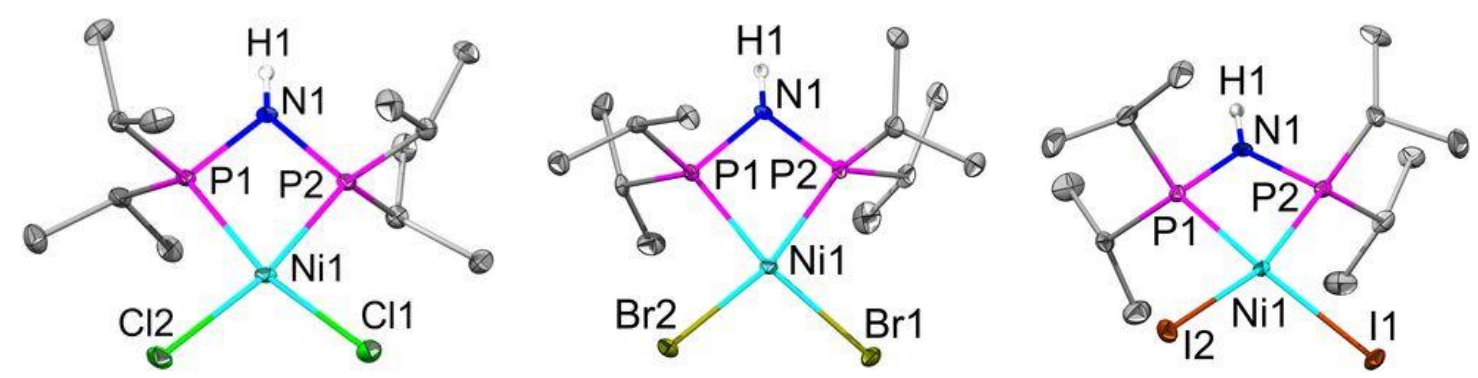

Fig. 1. Structures of (HL)NiX 2 complexes 1-3. Thermal ellipsoids are shown at 50\% probability and all hydrogen atoms except the N-H have been omitted for clarity.

Several different metal-ligand stoichiometries were screened during the preparations of 13, but the 1:1 complexes appeared to be the only substances formed when the anion was a simple halide. By switching to more complex, weakly coordinating anions, it was possible to prepare a series of $\mathrm{Ni}^{2+}$ complexes with a different coordination environment. When warm ethanol solutions of the green-colored nickel salts $\mathrm{Ni}\left(\mathrm{BF}_{4}\right)_{2} \cdot 6 \mathrm{H}_{2} \mathrm{O}, \mathrm{Ni}\left(\mathrm{NO}_{3}\right)_{2} \cdot 6 \mathrm{H}_{2} \mathrm{O}$, or $\mathrm{Ni}\left(\mathrm{ClO}_{4}\right)_{2} \cdot 6 \mathrm{H}_{2} \mathrm{O}$ are combined in a 1:2 ratio with the neutral HL ligand $\mathrm{HN}\left[\mathrm{P}(i-\mathrm{Pr})_{2}\right]_{2}$ (Scheme 1$)$, an immediate color change to orange-yellow occurs. Upon cooling, air- and moisture-stable yellow crystals with the formula $\left[(\mathrm{HL})_{2} \mathrm{Ni}\right] \mathrm{X}_{2}\left(\mathrm{X}=\mathrm{BF}_{4} 4 ; \mathrm{X}=\mathrm{NO}_{3} \mathbf{5} ; \mathrm{X}=\mathrm{ClO}_{4} \mathbf{6}\right)$ are obtained in good yields. As was the case with $\mathbf{1}$, these crystals obtained directly from the reaction mixture proved suitable for single crystal X-ray diffraction (Fig. 2). 

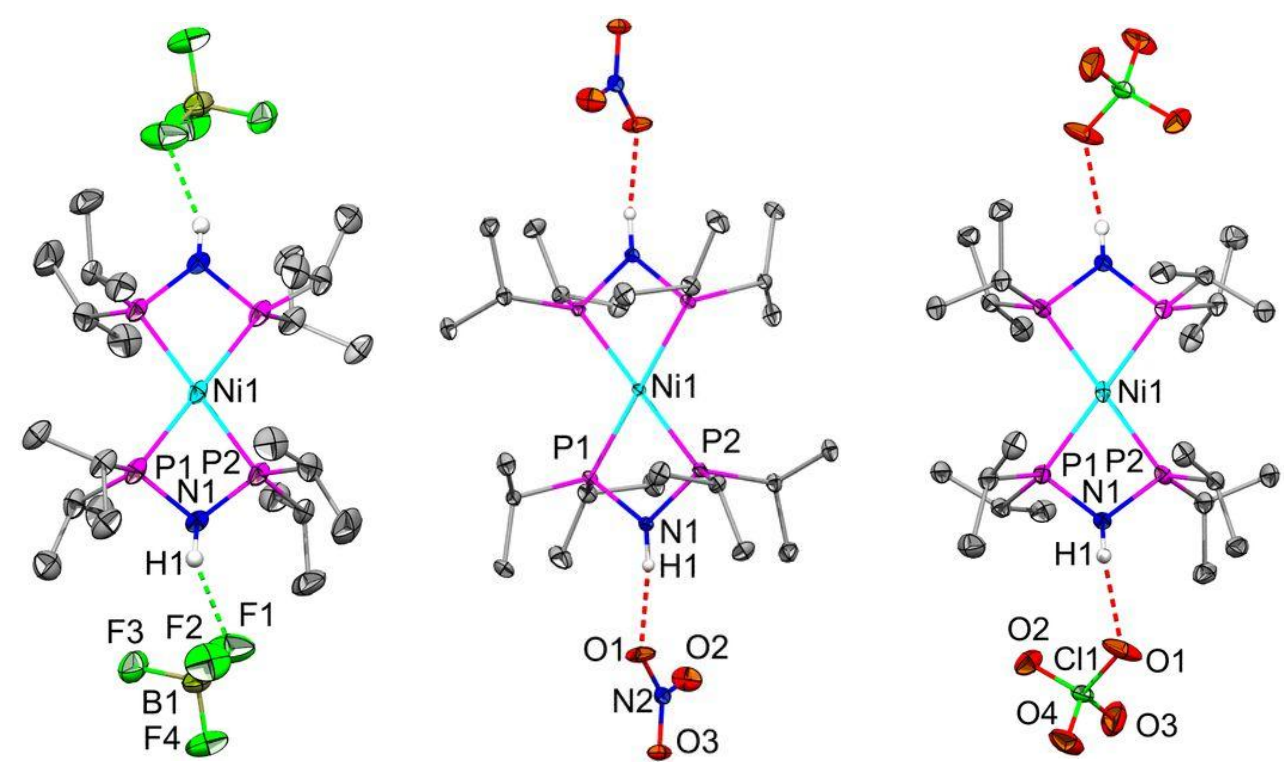

Fig. 2. Structures of $\left[(\mathrm{HL})_{2} \mathrm{Ni}\right] \mathrm{X}_{2}$ complexes 4-6. Thermal ellipsoids are shown at $50 \%$ probability and all hydrogen atoms except the $\mathrm{N}-\mathrm{H}$ have been omitted for clarity. Only the major position of the disordered $\mathrm{BF}_{4}$ anion of $\mathbf{4}$ is shown.

As with complexes 1-3, the structure solutions of 4-6 were very similar. Each one features a square planar $\mathrm{Ni}^{\mathrm{II}}$ center chelated by the four phosphorus atoms of two HL ligands. Again, the nitrogen atom of the ligand is bent slightly out of the $\mathrm{NiP}_{4}$ plane $(\mathbf{4}=0.141(2) \AA ; \mathbf{5}=$ $0.101(1) \AA ; 6=0.160(2) \AA)$, similarly to the $(\mathrm{HL}) \mathrm{NiX}_{2}$ complexes $\mathbf{1 - 3}$. In contrast to the hydrogen-bonded chains of 1-3, each NH in 4-6 forms a hydrogen bond to a fluorine (4) or oxygen $(5, \mathbf{6})$ of the outer-sphere anions, and there are no notable supramolecular interactions beyond these discrete ion pairs. With the exception of the Ni-P bonds, which are on average nearly $0.1 \AA$ longer in 4-6 than the corresponding bonds in $\mathbf{1 - 3}$, there is little difference in between the bond lengths and angles across the six compounds (Table 2).

Despite the different metal-ligand ratios and anion coordination, the complexes 4-6 were surprisingly found to be just as poorly soluble as the original set, so once again only the ${ }^{1} \mathrm{H}\left\{{ }^{31} \mathrm{P}\right\}$ and ${ }^{31} \mathrm{P}\left\{{ }^{1} \mathrm{H}\right\}$ NMR spectra were recorded. Complexes $\mathbf{4}$ and $\mathbf{6}$ had nearly identical ${ }^{31} \mathrm{P}\left\{{ }^{1} \mathrm{H}\right\}$ 
spectra, each a singlet at 70.7 and $70.9 \mathrm{ppm}$, respectively, while $\mathbf{5}$ was found slightly upfield at $67.4 \mathrm{ppm}$. As was the case with the chloride and bromide compounds $\mathbf{1}$ and $\mathbf{2}$, these resonances are very close to the signal of the free ligand, leaving the ${ }^{1} \mathrm{H}\left\{{ }^{31} \mathrm{P}\right\}$ NMR spectra as the best way to distinguish between product and starting material. Once again, the alkyl signals were shifted significantly downfield relative to the free ligand, with a single septet in each spectrum for the $\mathrm{CH}$ signal between 2.43-2.44 ppm for each of 4-6, while the two $\mathrm{CH}_{3}$ doublets were recorded between 1.35-1.37 and 1.46-1.47 ppm. For HL, the corresponding resonances are 1.61, 1.06, and 1.03 ppm, respectively. Despite the similarities in the alkyl region of their NMR spectra, the NH signal varied substantially from one complex to the next. For compounds $\mathbf{4}$ and $\mathbf{6}$, the $\mathrm{NH}$ resonance appears at $5.75 \mathrm{ppm}$ and $6.01 \mathrm{ppm}$, respectively, significantly downfield from the corresponding signals in 1-3 (3.07-3.27 ppm). Compound $\mathbf{5}$ is even more of an outlier, found at $8.36 \mathrm{ppm}$. A similar pattern was seen in the IR spectra. The $\mathrm{NH}$ stretches of $\mathbf{4}$ and $\mathbf{6}$ were found at 3244 and $3150 \mathrm{~cm}^{-1}$, respectively, close to those of 1-3 $\left(3186-3202 \mathrm{~cm}^{-1}\right)$, but 5 was quite different at $2569 \mathrm{~cm}^{-1}$. This is a region more typically associated with cationic NH groups.[26] Of the six complexes, $\mathbf{5}$ has the shortest $\mathrm{N}-\mathrm{H} \bullet \bullet \mathrm{X}$ hydrogen bond, which is perhaps why its $\mathrm{NH}$ stretch has such a different spectroscopic signature.

As noted earlier, complexes containing neutral HL were heretofore virtually unknown, but the use of it and related $\mathrm{HN}\left(\mathrm{PR}_{2}\right)_{2}$ ligands in their anionic form $\left[\mathrm{N}\left(\mathrm{PR}_{2}\right)_{2}\right]^{-}$is relatively widespread. HL can be deprotonated in situ by $\mathrm{NaNH}_{2}$ in $\mathrm{Et}_{2} \mathrm{O}$. Subsequent addition of $\mathrm{NiI}_{2}$ gives, after 24 hours, $\mathrm{L}_{2} \mathrm{Ni} 7$ (Scheme 2). The orange crystals of 7 were far more soluble than complexes 1-6, allowing for characterization by ${ }^{13} \mathrm{C}\left\{{ }^{1} \mathrm{H}\right\}$ NMR spectroscopy as well as ${ }^{1} \mathrm{H}\left\{{ }^{31} \mathrm{P}\right\}$ and ${ }^{31} \mathrm{P}\left\{{ }^{1} \mathrm{H}\right\}$ NMR spectroscopy. A single isopropyl environment was observed, with the $\mathrm{CH}$ and $\mathrm{CH}_{3}$ fragments at $1.88,1.41$, and $1.15 \mathrm{ppm}$ in the ${ }^{1} \mathrm{H}\left\{{ }^{31} \mathrm{P}\right\}$ NMR spectrum, and at 30.9, 
Table 2. Selected bond lengths $(\AA)$ and angles $\left({ }^{\circ}\right)$ of the nickel complexes 1-8.

\begin{tabular}{|c|c|c|c|c|c|c|c|c|c|}
\hline$\infty$ & 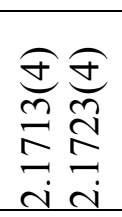 & 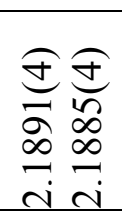 & 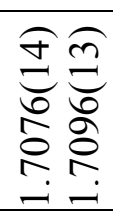 & 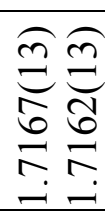 & & 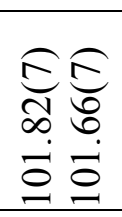 & 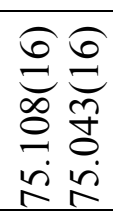 & & \\
\hline$\pi$ & 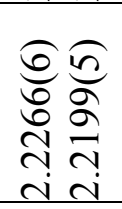 & 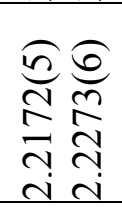 & 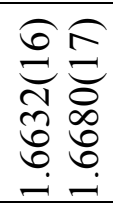 & 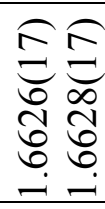 & & 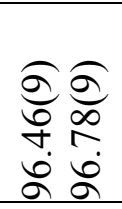 & 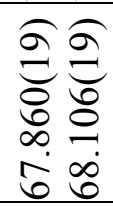 & 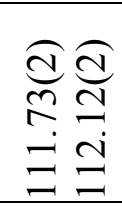 & \\
\hline$r$ & 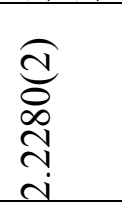 & 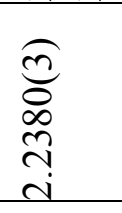 & 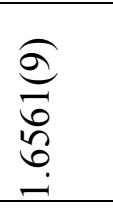 & 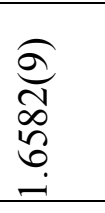 & & 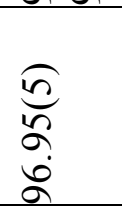 & 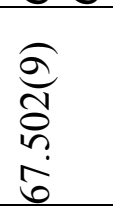 & $\begin{array}{l}\widehat{\hat{O}} \\
\infty \\
\stackrel{+}{+} \\
\stackrel{d}{\Xi}\end{array}$ & \\
\hline 6 & $\begin{array}{l}\underset{f}{+} \\
\underset{f}{2} \\
\stackrel{i}{i}\end{array}$ & 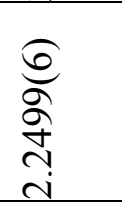 & 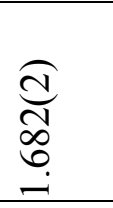 & 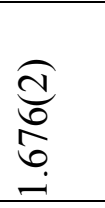 & \begin{tabular}{l}
$\widehat{0}$ \\
\multirow{+}{\infty}{} \\
$\infty$ \\
$i$ \\
$i$
\end{tabular} & 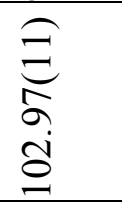 & $\begin{array}{l}\frac{a}{n} \\
\stackrel{n}{r}\end{array}$ & 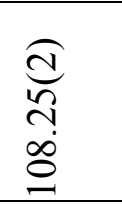 & 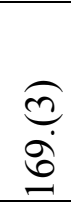 \\
\hline in & 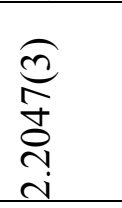 & 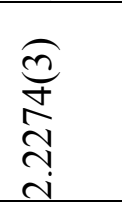 & 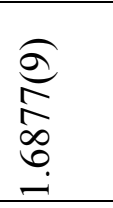 & $\begin{array}{l}\hat{\sigma} \\
\hat{\infty} \\
0 \\
0 \\
\dot{\theta}\end{array}$ & 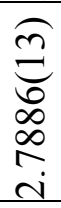 & $\begin{array}{l}\widehat{\sigma} \\
\stackrel{\infty}{\infty} \\
\dot{0} \\
0\end{array}$ & 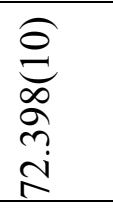 & 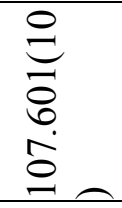 & 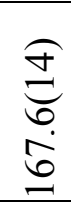 \\
\hline$\nabla$ & $\begin{array}{l}\widehat{\infty} \\
\infty \\
n \\
\tilde{n} \\
i \\
\end{array}$ & 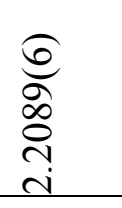 & 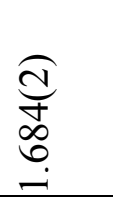 & $\begin{array}{l}\widehat{d} \\
\infty \\
\infty \\
0 \\
\stackrel{-}{0}\end{array}$ & $\begin{array}{l}\widehat{0} \\
\text { ڤ్ } \\
\infty \\
i \\
i\end{array}$ & 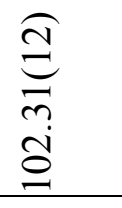 & $\begin{array}{l}\widehat{d} \\
\text { o } \\
\text { i }\end{array}$ & 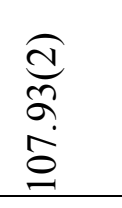 & $\begin{array}{c}\text { (ூ) } \\
\stackrel{n}{n}\end{array}$ \\
\hline$m$ & 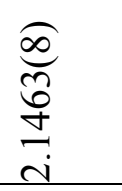 & $\begin{array}{l}\underset{\infty}{\infty} \\
\stackrel{\oplus}{ \pm} \\
i\end{array}$ & $\begin{array}{l}\overparen{0} \\
\infty \\
\infty \\
0 \\
\end{array}$ & $\begin{array}{l}\hat{0} \\
\stackrel{0}{0} \\
\stackrel{0}{0}\end{array}$ & \begin{tabular}{l}
$\widehat{d}$ \\
on \\
\multirow{0}{0}{} \\
$\dot{c}$
\end{tabular} & $\begin{array}{l}\underset{n}{n} \\
\stackrel{n}{n} \\
\infty \\
a\end{array}$ & 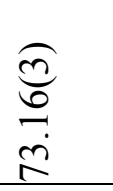 & & @ே! \\
\hline$N$ & 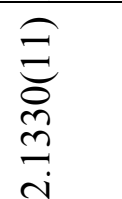 & 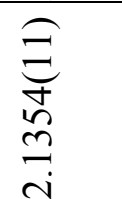 & 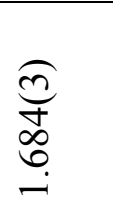 & 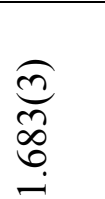 & $\begin{array}{l}\widehat{0} \\
\text { on } \\
0 \\
\dot{m}\end{array}$ & 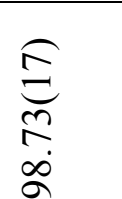 & 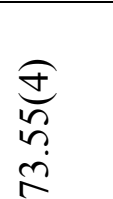 & & 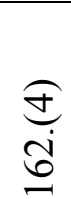 \\
\hline- & 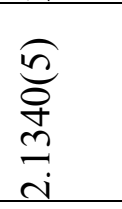 & $\begin{array}{l}\sqrt[\sigma]{n} \\
\stackrel{n}{n} \\
\stackrel{2}{i}\end{array}$ & 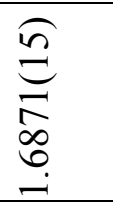 & $\begin{array}{l}\underset{n}{\tilde{n}} \\
\underset{+}{\sigma} \\
\infty \\
0 \\
0 \\
-1\end{array}$ & 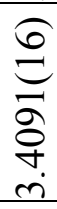 & $\begin{array}{l}\hat{\alpha} \\
\stackrel{a}{a} \\
\hat{a}\end{array}$ & $\underset{\stackrel{\infty}{\approx}}{\stackrel{\infty}{\approx}}$ & & $\begin{array}{l}\text { త్ర } \\
\stackrel{0}{n} \\
\end{array}$ \\
\hline & $\frac{\overline{i_{1}}}{\overline{\bar{z}}}$ & $\frac{\tilde{1}}{\bar{z}}$ & $\bar{z}$ & 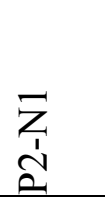 & $\begin{array}{c}x \\
\vdots \\
\dot{z}\end{array}$ & $\frac{\tilde{1}}{\tilde{I}_{1}}$ & $\frac{\stackrel{1}{1}}{\frac{1}{2}}$ & $\frac{\bar{i}}{\bar{Z}}$ & 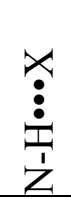 \\
\hline
\end{tabular}


19.0, and $16.7 \mathrm{ppm}$ in the $13 \mathrm{C}\{1 \mathrm{H}\}$ NMR spectrum. Likewise, a single $31 \mathrm{P}\{1 \mathrm{H}\}$ peak was observed, with the somewhat unexpected chemical shift of $24.3 \mathrm{ppm}$. This is far upfield from the previously reported complexes featuring anionic $\mathrm{L}^{-}$as either a $\mathrm{P}, \mathrm{P}$-chelating ligand in $\mathrm{L}_{2} \mathrm{Zn}$ (91.4 ppm),[16] $\mathrm{L}_{2} \mathrm{Sn}(80.2 \mathrm{ppm}),[17] \mathrm{L}_{2} \mathrm{SnCl}_{2}(127.1 \mathrm{ppm})[27]$ and $\mathrm{L}_{2} \mathrm{InCl}(122 \mathrm{ppm})[18]$ or as a P,P-bridging ligand in $(\mathrm{LSn})_{2}$ or $(\mathrm{LGe})_{2}$ at 98.3 and $103.5 \mathrm{ppm}$, respectively.[27]

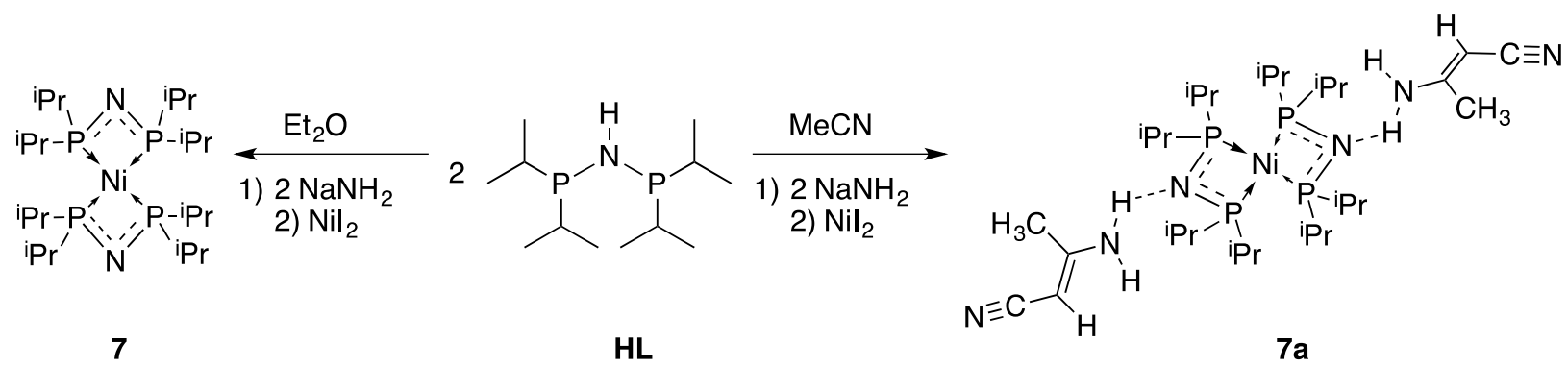

Scheme 2. Synthesis of $\mathrm{L}_{2} \mathrm{Ni} 7$ and $\mathrm{L}_{2} \mathrm{Ni} \cdot 2\left[\mathrm{NCCHC}(\mathrm{Me}) \mathrm{NH}_{2}\right] 7 \mathbf{a}$.

The structure of 7 was confirmed by single crystal X-ray diffraction (Fig. 3). The square planar $\mathrm{Ni}^{\mathrm{II}}$ ion is $\mathrm{P}, \mathrm{P}$-chelated by two ligands, just as in the cores of the $\left[(\mathrm{HL})_{2} \mathrm{Ni}\right] \mathrm{X}_{2}$ complexes 4-6. Although one might expect the Ni-P bonds to be shorter with an anionic rather than a neutral ligand, they are instead quite similar in length to 4-6. The P-N bonds, however, are slightly shorter and the P-N-P and P-Ni-P (chelate) angles are more acute than any found in 1-6.

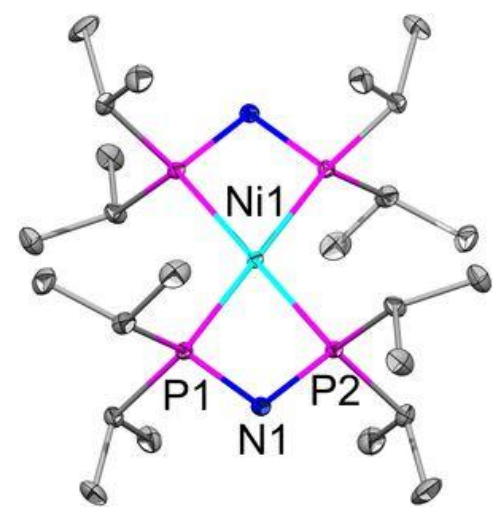

Fig. 3. Structure of $\mathrm{L}_{2} \mathrm{Ni}$ complex 7. Thermal ellipsoids are shown at $50 \%$ probability and hydrogen atoms have been omitted for clarity. 
Because 7 took significantly longer to form than the neutral-ligand complexes 1-6, a number of different solvents and deprotonating agents were screened in an attempt to improve the reaction rate. Initially, acetonitrile appeared to be a much better solvent than the diethyl ether for this synthesis. By ${ }^{31} \mathrm{P}\left\{{ }^{1} \mathrm{H}\right\}$ NMR spectroscopy, the conversion was complete in about four hours instead of twenty four hours, and the yield of orange powder after work-up was higher. Further characterization, however, indicated that it was not pure 7 that had been isolated from the $\mathrm{MeCN}$ solution. The melting point of this product 7a was significantly lower and both the ${ }^{1} \mathrm{H}\left\{{ }^{31} \mathrm{P}\right\}$ and ${ }^{13} \mathrm{C}\left\{{ }^{1} \mathrm{H}\right\}$ NMR spectra had, in addition to the peaks that corresponded to 7, extra peaks that were inconsistent with either HL or the reaction solvent. To determine the nature of this product, single crystals of $7 \mathbf{a}$ were grown from a concentrated $\mathrm{CH}_{2} \mathrm{Cl}_{2}$ solution.

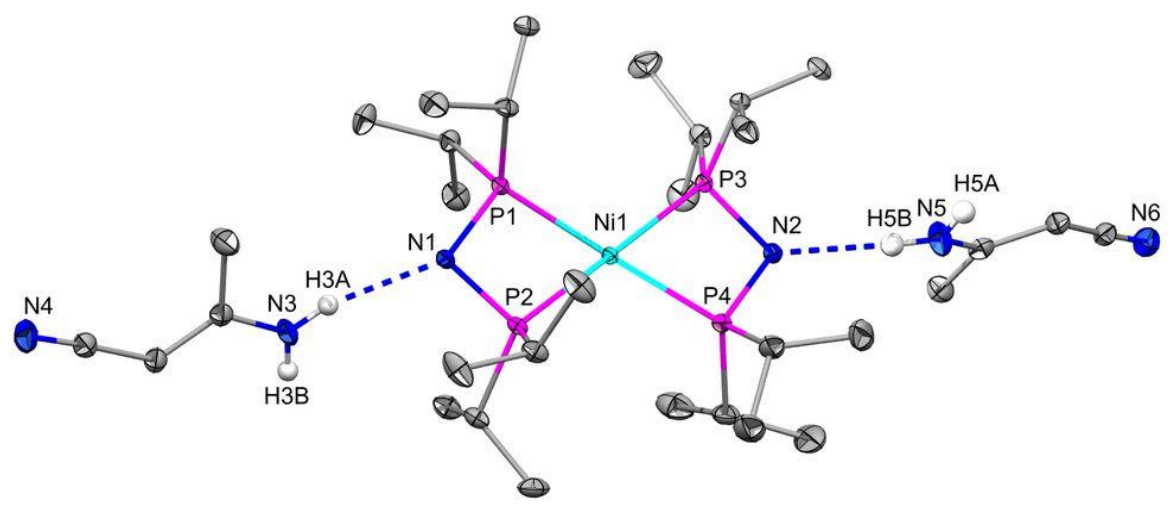

Fig. 4. Structure of $\mathrm{L}_{2} \mathrm{Ni} \cdot 2\left[\mathrm{NCCHC}(\mathrm{Me}) \mathrm{NH}_{2}\right]$ 7a. Thermal ellipsoids are shown at $50 \%$ probability and all hydrogen atoms except the N-H have been omitted for clarity.

The structure was solved as a 1:2 co-crystal of 7 and 3-amino-2-butenenitrile, also known as 3-aminocrotonitrile (Fig. 4). In addition to deprotonating $\mathbf{H L}$, the $\mathrm{NaNH}_{2}$ quite unexpectedly promotes a Thorpe reaction[28] of the acetonitrile solvent, thus leading to the formation of the 3amino-2-butenenitrile. This molecule engages in extensive hydrogen-bonding (Fig. 5), preventing its removal during normal work-up procedures. The amine end of the 3-amino-2- 
butenenitrile acts as a hydrogen bond donor, and the nitrile end acts as an acceptor, forming infinite chains with itself. These chains are cross-linked by the nickel complex whose deprotonated $\mathrm{N}$ atoms also behave as hydrogen bond acceptors; interestingly, the opposite role that they play in their neutral form in 1-6. Despite its versatility in hydrogen bonding, being known since at least 1889,[29] and being commercially available from several suppliers, crystal structures containing 3-amino-2-butenenitrile have been reported only twice before - once as a co-crystal with tetramethylammonium fluoride[30] and just last year as the discrete molecule.[31]

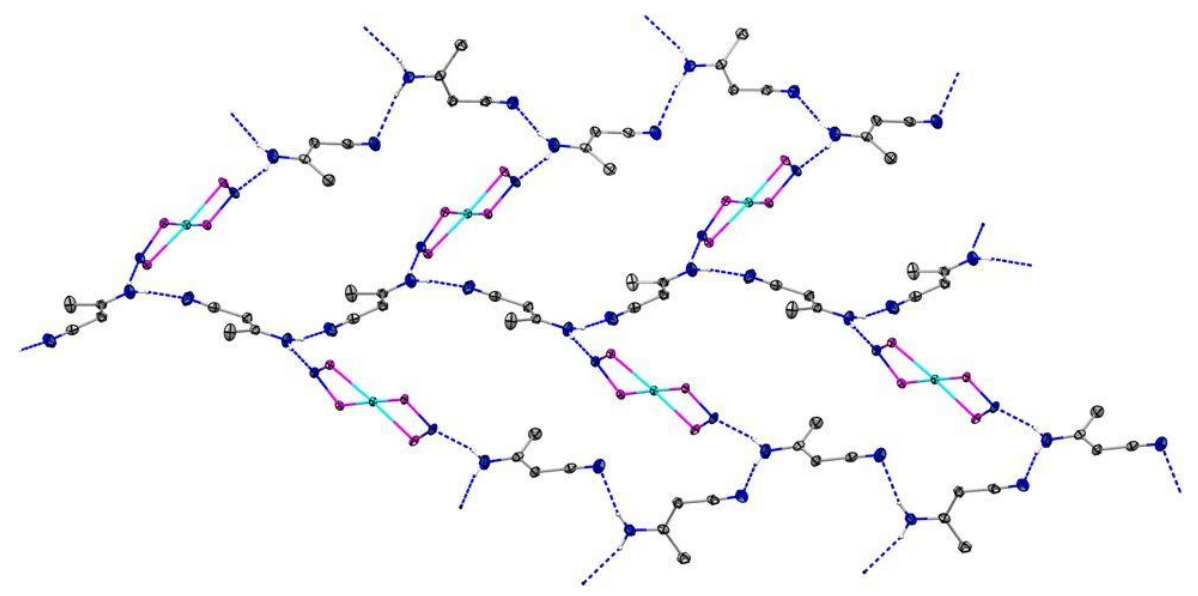

Fig. 5. Hydrogen-bonding in 7a. Isopropyl groups omitted for clarity.

Although $\mathrm{Ni}^{\mathrm{II}}$ is the oxidation state for many of the applications noted in the introduction, $\mathrm{Ni}^{0}$ is also very commonly used. Using a ligand closely related to $\mathbf{H L}$, namely $\mathrm{HN}\left(\mathrm{PPh}_{2}\right)_{2}$, Kornev et al. reported that they were unable to obtain the corresponding homoleptic $\mathrm{Ni}^{0}$ complex from $\mathrm{Ni}(\mathrm{cod})_{2}$ but they were able to isolate a heteroleptic complex $\left[\mathrm{HN}\left(\mathrm{PPh}_{2}\right)_{2}\right] \mathrm{Ni}\left(\mathrm{PPh}_{3}\right)_{2} \cdot[13 \mathrm{a}]$ Kubiak et al. found that in the presence of various isocyanides, the reaction of $\mathrm{Ni}(\operatorname{cod})_{2}$ and $\mathrm{HN}\left(\mathrm{PPh}_{2}\right)_{2}$ also gives heteroleptic complexes, although in that case the $\mathrm{HN}\left(\mathrm{PPh}_{2}\right)_{2}$ ligands bridged two metal centers instead of acting as a chelate to a single nickel atom.[32] 
In light of those precedents, we were unsure what to expect from the reaction of $\mathrm{Ni}(\operatorname{cod})_{2}$ with two equivalents of $\mathbf{H L}$ (Scheme 3). The reaction was monitored by ${ }^{31} \mathrm{P}\left\{{ }^{1} \mathrm{H}\right\}$ NMR spectroscopy which showed the clean formation of a single product $\mathbf{8}$ over the course of a few hours. This is consistent with our prior observations (vide supra) that there is often a great difference in reactivity when phenyl substituents are replaced with isopropyl groups. The ${ }^{31} \mathrm{P}\left\{{ }^{1} \mathrm{H}\right\}$ NMR spectrum of $\mathbf{8}$ is a singlet at $97.9 \mathrm{ppm}$, the most downfield of all the compounds described herein. In the ${ }^{1} \mathrm{H}\left\{{ }^{31} \mathrm{P}\right\}$ spectrum, the signals assigned to the isopropyl $\mathrm{CH}$ and $\mathrm{CH}_{3}$ groups were observed as a septet at 1.90 and doublets at 1.21 and $1.23 \mathrm{ppm}$. Consistent with an absence of hydrogen bond acceptors, the $\mathrm{N} H$ was found at $1.72 \mathrm{ppm}$ in the NMR spectrum and $3323 \mathrm{~cm}^{-1}$ in the IR spectrum. Neither the ${ }^{1} \mathrm{H}\left\{{ }^{31} \mathrm{P}\right\}$ nor the ${ }^{13} \mathrm{C}\left\{{ }^{1} \mathrm{H}\right\}$ spectra showed any resonances corresponding to cyclooctadiene, suggesting that $\mathbf{8}$ was a homoleptic species.

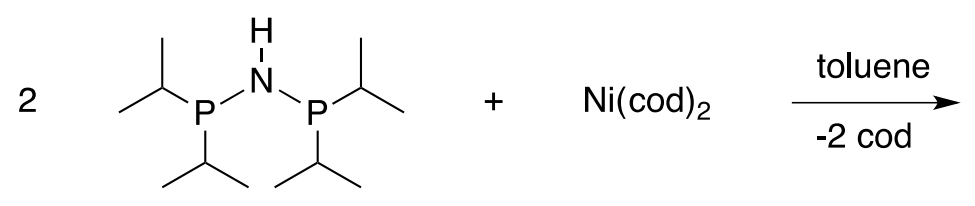

HL

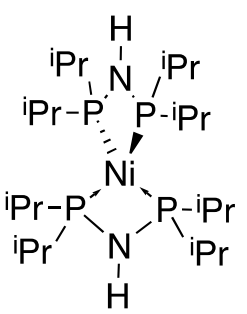

8

Scheme 3. Synthesis of the $\mathrm{Ni}^{0}$ complex 8 .

Since $\mathrm{HL}$ and $\mathrm{Ni}(\mathrm{cod})_{2}$ were combined in a 2:1 ratio and no unreacted ligand was found to persist in the crude reaction mixture, it seemed most likely that $\mathbf{8}$ was a chelate complex of the form $(\mathrm{HL})_{2} \mathrm{Ni}$, rather than a P,P-bridged $[(\mathrm{HL}) \mathrm{Ni}]_{2}$. Single crystals were grown from a concentrated pentane solution and the structure was confirmed as (HL) $)_{2} \mathrm{Ni}$ (Fig. 6). As one would expect upon switching from the $\mathrm{d}^{8} \mathrm{Ni}^{\mathrm{II}}$ centers of $1-7 \mathbf{a}$ to the $\mathrm{d}^{10} \mathrm{Ni}^{0}$ configuration of $\mathbf{8}$, the coordination geometry at nickel is now tetrahedral instead of square planar. The Ni-P bond 
lengths (Table 2) are within the range of those noted for 1-7a, despite the difference in charge at the metal center. The P-N bonds, however, are not only longer than in the other complexes, but are slightly longer on average than in the free ligand[17] itself $(\mathbf{H L}=1.705(4) \AA, 8=$ average 1.712(13) $\AA$ ). This is consistent with backbonding between the $\mathrm{Ni}^{0}$ and $\mathrm{P}$ weakening the $\mathrm{P}-\mathrm{N}$ bonds.

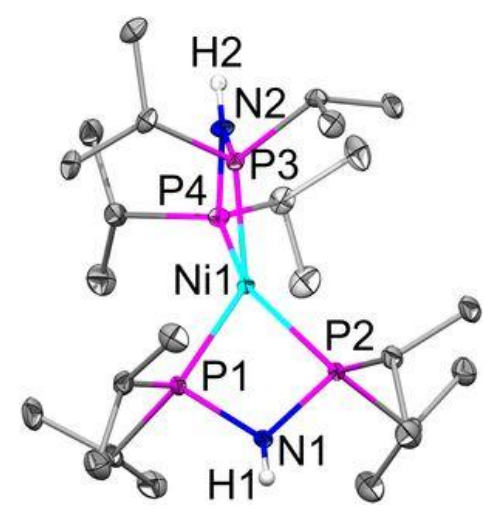

Fig. 6. Structure of $(\mathrm{HL})_{2} \mathrm{Ni}$ complex $\mathbf{8}$. Thermal ellipsoids are shown at $50 \%$ probability and all hydrogen atoms except the N-H have been omitted for clarity.

\subsection{Electrochemistry}

Compounds 1, 2, and 3 display very similar cathodic behaviors. For each compound at least four modestly spaced diffusion-controlled chemically-irreversible cathodic reductions were observed at the potentials collected in Table 3 . Some smaller oxidation waves were also observed during the back scan and those are presumably due to the presence of decomposed reduced products (Fig. 7). No peak was observed in the oxidative region.

Bulk coulometry at the potential of the first cathodic wave confirmed that the first redox event is a one-electron process. Unfortunately, the rapid decomposition of the monoelectronically reduced product did not allow identification of its structure. The peak potential of 
the first reduction wave decreases when chloride (1) is replaced by bromide (2), and is even lower when replaced by iodide (3). This tends to suggest that the electrochemical reduction of those compounds involve the reduction of the metal-halogen bond as the first step.[33] Although the formation of a transient $\mathbf{1}^{-}, \mathbf{2}^{-}$, or $\mathbf{3}^{-}$could not be ruled out, the lack of reversibility of the first reduction at higher sweeping rates (up to $\left.250,000 \mathrm{~V} \cdot \mathrm{s}^{-1}\right)$ and at low temperature $\left(-50^{\circ} \mathrm{C}\right)$ suggests that the electron transfer might be coupled to the cleavage of the nickel-halogen bond. In addition to the chemical irreversibility, $\mathbf{1}, \mathbf{2}$ as well as $\mathbf{3}$ display an important degree of electrochemical irreversibility.[34] The measured $E_{p}-E_{p / 2}$ values for the first reduction of these complexes are diagnostic of a slow charge transfer process with coefficient $(\alpha)$ of $0.28,0.34$, and 0.37, respectively.[34] Finally, in presence of $\mathrm{CO}_{2}$, no change has been observed during the cyclic voltammetry and bulk electrolysis experiments.

Table 3. Electrochemical parameters for compounds 1, 2 and $\mathbf{3 .}$

\begin{tabular}{|l|l|l|l|l|l|}
\hline Compound & $\begin{array}{l}\text { First } \\
\text { reduction }\end{array}$ & $\mathrm{E}_{\mathrm{p}}-\mathrm{E}_{\mathrm{p} / 2}$ & $\begin{array}{l}\text { Second } \\
\text { reduction }\end{array}$ & $\begin{array}{l}\text { Third } \\
\text { reduction }\end{array}$ & $\begin{array}{l}\text { Fourth } \\
\text { reduction }\end{array}$ \\
\hline $\mathbf{1}$ & $\mathrm{E}_{\mathrm{pc}}=-1.93 \mathrm{~V}$ & $170 \mathrm{mV}$ & $\mathrm{E}_{\mathrm{pc}}=-2.28 \mathrm{~V}$ & $\mathrm{E}_{\mathrm{pc}}=-2.44 \mathrm{~V}$ & $\mathrm{E}_{\mathrm{pc}}=-2.97 \mathrm{~V}$ \\
\hline $\mathbf{2}$ & $\mathrm{E}_{\mathrm{pc}}=-1.86 \mathrm{~V}$ & $140 \mathrm{mV}$ & $\mathrm{E}_{\mathrm{pc}}=-2.16 \mathrm{~V}$ & $\mathrm{E}_{\mathrm{pc}}=-2.50 \mathrm{~V}$ & $\mathrm{E}_{\mathrm{pc}}=-2.96 \mathrm{~V}$ \\
\hline $\mathbf{3}$ & $\mathrm{E}_{\mathrm{pc}}=-1.73 \mathrm{~V}$ & $130 \mathrm{mV}$ & $\mathrm{E}_{\mathrm{pc}}=-1.94 \mathrm{~V}$ & $\mathrm{E}_{\mathrm{pc}}=-2.46 \mathrm{~V}$ & $\mathrm{E}_{\mathrm{pc}}=-2.91 \mathrm{~V}$ \\
\hline
\end{tabular}




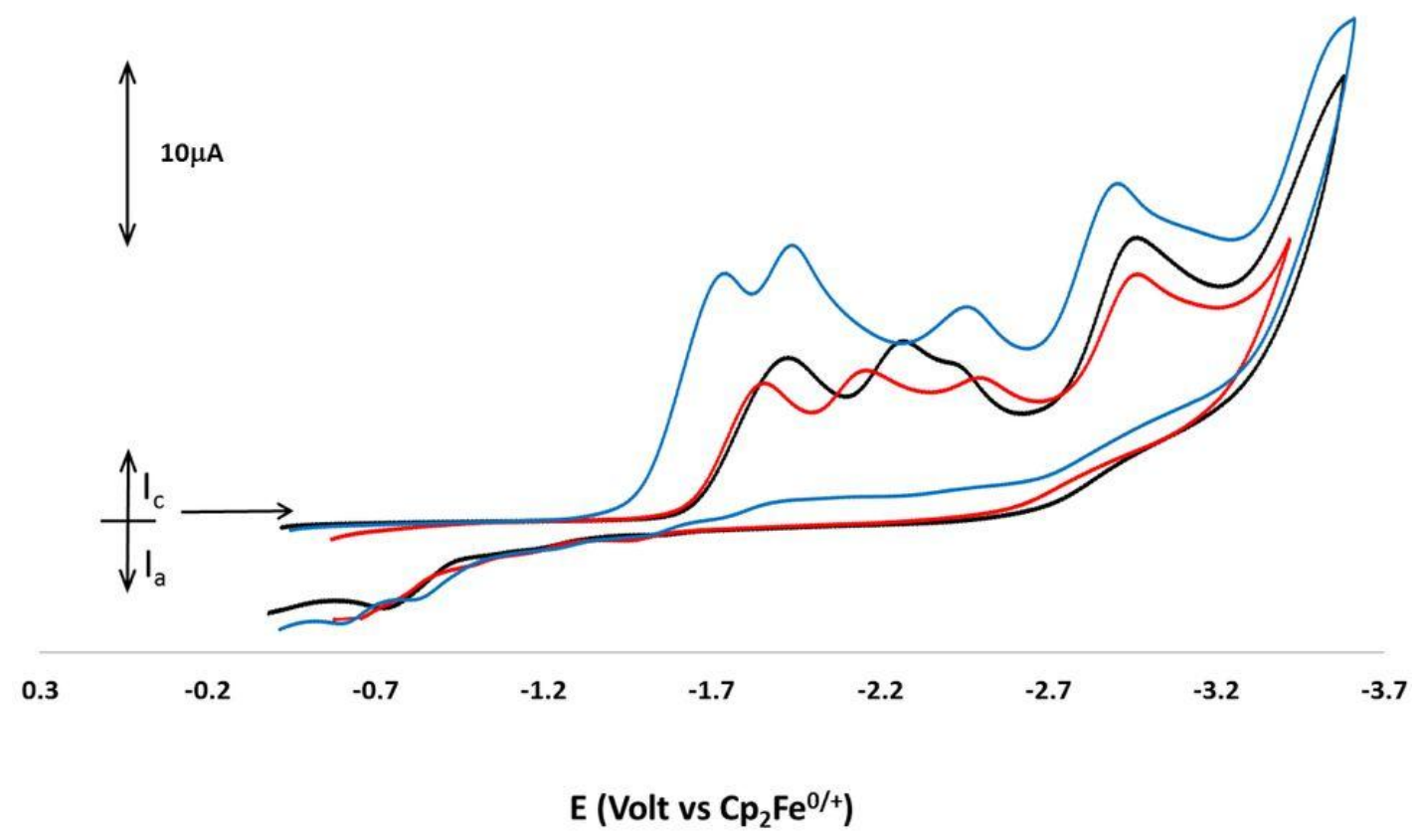

Figure 7. Cyclic Voltammetry scan of $1 \mathrm{mM} \mathrm{1,2}$ and $\mathbf{3}$ in THF/0.1M $\left[\mathrm{NBu}_{4}\right]\left[\mathrm{PF}_{6}\right]$ at $3 \mathrm{~mm}$ glassy carbon electrode, scan rate $0.2 \mathrm{~V} \mathrm{~s}^{-1}$.

Compounds 4, 5, and 6 display again very similar redox behaviors. Although only compound $\mathbf{6}$ proved to be totally soluble under our electrochemical conditions, $\mathbf{4}$ and $\mathbf{5}$ were soluble enough to yield reliable electrochemical data. Each of the complexes demonstrates two reduction waves with significant chemical reversibility (Fig. 8), which is consistent with the reduction of the nickel center from $\mathrm{Ni}^{\mathrm{II}}$ to $\mathrm{Ni}^{\mathrm{I}}$ and then from $\mathrm{Ni}^{\mathrm{I}}$ to $\mathrm{Ni}^{0}$. The $\mathrm{E}_{1 / 2}$ values for those oxidations are very similar for each complex and are summarized in Table 4. Moreover, bulk electrolysis of compound 6 , under argon atmosphere, at $-1.30 \mathrm{~V}$ and at $-1.60 \mathrm{~V}$ confirmed that both reduction processes involve a one-electron transfer. In addition, the $\mathrm{Ni}^{\mathrm{I}}$ and $\mathrm{Ni}^{0}$ reduced forms of the complex have been found to be stable under the bulk electrolysis conditions since their re-oxidation led to the quantitative reformation of the starting material.

Table 4. Electrochemical parameters for compounds $\mathbf{4 , 5}$ and $\mathbf{6}$ under argon. 


\begin{tabular}{|l|l|l|l|l|l|l|}
\hline Compound & $\mathrm{E}_{\mathrm{pc}}^{1}$ & $\mathrm{E}_{\mathrm{pa}}^{1}$ & $\mathrm{E}_{1 / 2}^{1}$ & $\mathrm{E}_{\mathrm{pc}}^{2}$ & $\mathrm{E}_{\mathrm{pa}}^{2}$ & $\mathrm{E}_{1 / 2}^{2}$ \\
\hline $\mathbf{4}$ & $-1.04 \mathrm{~V}$ & $-0.90 \mathrm{~V}$ & $-0.97 \mathrm{~V}$ & $-1.51 \mathrm{~V}$ & $-1.39 \mathrm{~V}$ & $-1.45 \mathrm{~V}$ \\
\hline $\mathbf{5}$ & $-1.13 \mathrm{~V}$ & -0.99 & $-1.06 \mathrm{~V}$ & $-1.59 \mathrm{~V}$ & $-1.47 \mathrm{~V}$ & $-1.53 \mathrm{~V}$ \\
\hline $\mathbf{6}$ & $-1.11 \mathrm{~V}$ & $-0.91 \mathrm{~V}$ & $-1.01 \mathrm{~V}$ & $-1.56 \mathrm{~V}$ & $-1.42 \mathrm{~V}$ & $-1.49 \mathrm{~V}$ \\
\hline
\end{tabular}

In presence of $\mathrm{CO}_{2}$, cyclic voltammograms of compounds $\mathbf{4 , 5}$, and $\mathbf{6}$ exhibit significantly different features showing a reaction between the low valent compound and carbon dioxide (Table 5). The fact that the reduction potentials for the two redox events are similar to those previously recorded in absence of $\mathrm{CO}_{2}$ suggests that the compounds are unlikely to spontaneously form a $\mathrm{CO}_{2}$ adduct prior to their reduction. More specifically, for complexes $\mathbf{5}$ and 6, no change was observed to the first reduction process when scanning until $-1.20 \mathrm{~V}$. However, scanning past the second reduction wave showed a complete loss of chemical reversibility for both reductions as well as a significant increase of current for the second reduction wave. This indicates that the $\mathrm{Ni}^{0}$ form of the complex is reacting with $\mathrm{CO}_{2}$ and proceeds presumably via an outer-sphere process.[35] Surprisingly, in the case of compound 4, both reduction waves showed an increase of current under $\mathrm{CO}_{2}$ conditions suggesting a more intricate mechanism. As expected, chemical reversibility as well as the original electrochemical features of each compound were restored after purging the solution with argon. Bulk electrolysis of compound 6 at $-1.6 \mathrm{~V}$ under $\mathrm{CO}_{2}$ never reached completion even after passing 9F/mol. However, when the bulk electrolysis cell was purged with argon and the electrolysis resumed, the cathodic reduction of compound $\mathbf{6}$ was achieved after passing $2 \mathrm{~F} / \mathrm{mol}$. This suggest that the reduced form of the catalyst is able to perform catalytic electroreduction of $\mathrm{CO}_{2}$. Efforts are underway to fully characterize the products of the irreversible oxidations in presence of $\mathrm{CO}_{2}$.

Table 5. Electrochemical parameters for compounds 4, 5 and $\mathbf{6}$ in presence of $\mathrm{CO}_{2}$ 


\begin{tabular}{|l|l|l|l|l|}
\hline Compound & $\mathrm{E}_{\mathrm{pc}}^{1}$ & $\mathrm{I}_{\mathrm{pccat}}^{1}{ }^{1} \mathrm{I}_{\mathrm{pc} 0}$ & $\mathrm{E}_{\mathrm{pc}}^{2}$ & $\mathrm{I}_{\mathrm{pccat}}^{2}{ }^{2} \mathrm{I}_{\mathrm{pc} 0}$ \\
\hline $\mathbf{4}$ & $-1.14 \mathrm{~V}$ & 6.6 & $-1.79 \mathrm{~V}$ & 6.6 \\
\hline $\mathbf{5}$ & $-1.13 \mathrm{~V}$ & $/$ & $-1.59 \mathrm{~V}$ & 14.4 \\
\hline $\mathbf{6}$ & $-1.11 \mathrm{~V}$ & $/$ & $-1.56 \mathrm{~V}$ & 2.0 \\
\hline
\end{tabular}

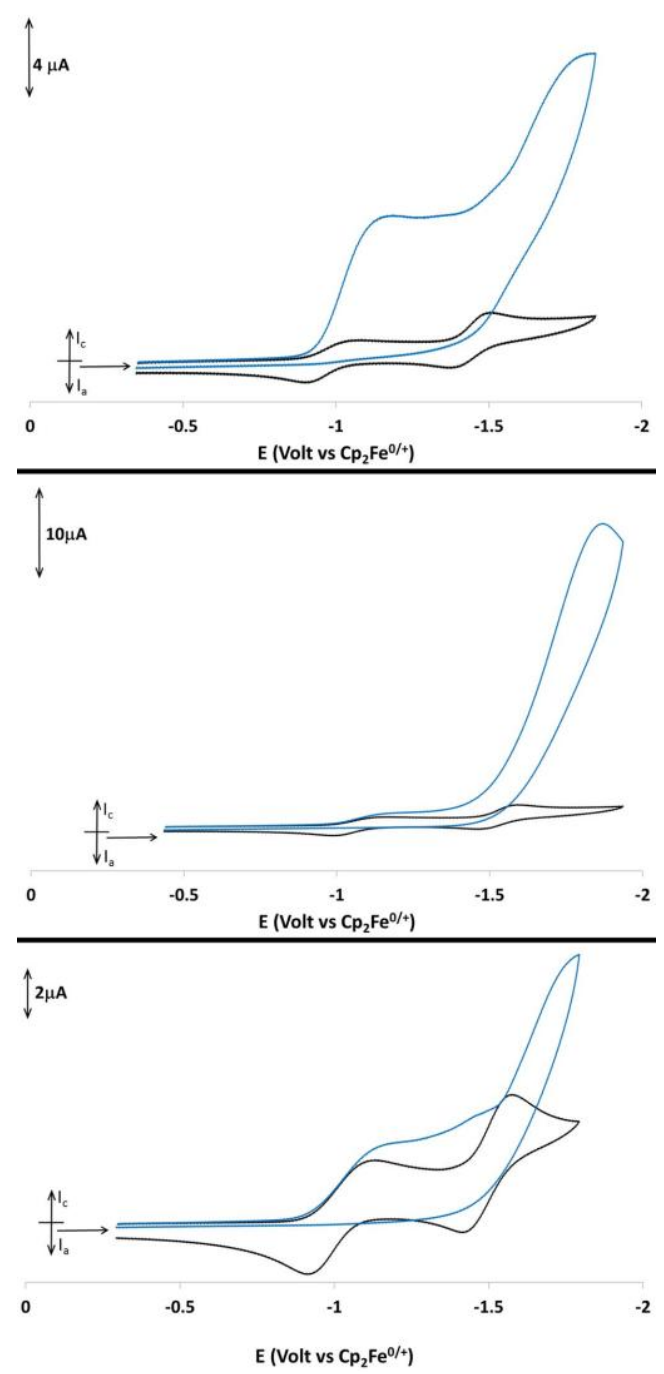

Figure 8. Cyclic Voltammetry scan of 4 (top), 5 (middle) and 6 (bottom) in THF/0.1M $\left[\mathrm{NBu}_{4}\right]\left[\mathrm{PF}_{6}\right]$ at $3 \mathrm{~mm}$ glassy carbon electrode, scan rate $0.2 \mathrm{~V} \mathrm{~s}^{-1}$ under argon (black curve) and under $\mathrm{CO}_{2}$ (blue curve) atmosphere. 


\section{CONCLUSIONS}

Six air- and moisture-stable $\mathrm{Ni}^{\mathrm{II}}$ complexes of bis(diisopropylphosphino)amine (HL) were prepared from either a 1:1 ratio of $\mathbf{H L}$ with $\mathrm{NiCl}_{2} \cdot 6 \mathrm{H}_{2} \mathrm{O}, \mathrm{NiBr}_{2}$, and $\mathrm{NiI}_{2}$, or a 2:1 ratio of HL with $\mathrm{Ni}\left(\mathrm{BF}_{4}\right)_{2} \bullet 6 \mathrm{H}_{2} \mathrm{O}, \mathrm{Ni}\left(\mathrm{NO}_{3}\right)_{2} \bullet 6 \mathrm{H}_{2} \mathrm{O}$, and $\mathrm{Ni}\left(\mathrm{ClO}_{4}\right)_{2} \bullet 6 \mathrm{H}_{2} \mathrm{O}$, all in ethanol solutions. The resulting complexes, which took the form of either $(\mathbf{H L}) \mathrm{NiX}_{2}(\mathrm{X}=\mathrm{Cl}, \mathrm{Br}, \mathrm{I})$ or $\left[(\mathbf{H L})_{2} \mathrm{Ni}\right] \mathrm{X}_{2}(\mathrm{X}$ $=\mathrm{BF}_{4}, \mathrm{NO}_{3}, \mathrm{ClO}_{4}$ ), were characterized by IR and multi-nuclear NMR spectroscopy as well as single-crystal X-ray diffraction. In tests of their ability to act as electrocatalysts for the reduction of $\mathrm{CO}_{2}$, the simple halides $(\mathrm{HL}) \mathrm{NiX}_{2}(\mathrm{X}=\mathrm{Cl}, \mathrm{Br}, \mathrm{I})$ were found to undergo chemical and electrochemical irreversible reductions. Electrocatalytic reduction of $\mathrm{CO}_{2}$ was possible with the $\left[(\mathbf{H L})_{2} \mathrm{Ni}\right] \mathrm{X}_{2}\left(\mathrm{X}=\mathrm{BF}_{4}, \mathrm{NO}_{3}, \mathrm{ClO}_{4}\right)$ complexes. The synthesis and characterization of the $\mathrm{Ni}^{0}$ complex $(\mathbf{H L})_{2} \mathrm{Ni}$ and the $\mathrm{Ni}^{\mathrm{II}}$ complexes $\mathbf{L}_{2} \mathrm{Ni}$ and $\mathbf{L}_{2} \mathrm{Ni} \cdot 2\left[\mathrm{NCCHC}(\mathrm{Me}) \mathrm{NH}_{2}\right]$ were also described.

\section{Acknowledgments}

Dr. Beth Donovan (UNM) and Mr. Nate Wilson (SNL) performed preliminary electrochemical experiments on 5. Mr. Jeremiah Sears (SNL) performed the elemental analysis on compounds 7 and $\mathbf{7 a}$. This work was financially supported by the National Science Foundation (Grant CHE12-13529), the Sandia National Laboratories-sponsored STAR Summer Fellows program, and the Kazakh Ministry of Education and Science. The Bruker X-ray diffractometer was purchased via a National Science Foundation CRIF:MU award to the University of New Mexico (CHE04-43580), and the NMR spectrometers were upgraded via grants from the NSF (CHE08-40523 and CHE09-46690). Sandia is a multiprogram laboratory 
operated by Sandia Corporation, a Lockheed Martin Company, for the U.S. Department of Energy's National Nuclear Security Administration under Contract DE-AC04-94-AL85000.

\section{References}

[1] E.A. LaPierre, W.E. Piers, D.M. Spasyuk, D.W. Bi, Chem. Commun., 52 (2016) 1361-1364. [2] A.N. Desnoyer, E.G. Bowes, B.O. Patrick, J.A. Love, J. Am. Chem. Soc., 137 (2015) 1274812751.

[3] K.T. Horak, S. Lin, J. Rittle, T. Agapie, Organometallics, 34 (2015) 4429-4432.

[4] T. Rosser, M.A. Gross, Y.-H. Lai, E. Reisner, Chem. Sci., 7 (2016) 4024-4035.

[5] (a) M. Schultz, F. Eisenträger, C. Regius, F. Rominger, P. Hanno-Igels, P. Jakob, I. Gruber, P. Hofmann, Organometallics, 31 (2012) 207-224; (b) P. Boulens, M. Lutz, E. Jeanneau, H. Olivier-Bourbigou, J.N.H. Reek, P.-A.R. Breuil, Eur. J. Inorg. Chem., (2014) 37543762; (c) A. Ghisolfi, C. Fliedel, V. Rosa, K.Y. Monakhov, P. Braunstein, Organometallics, 33 (2014) 2523-2534.

[6] (a) A. Mifleur, H. Ledru, A. Lopes, I. Suisse, A. Mortreux, M. Sauthier, Adv. Synth. Catal., 358 (2016) 110-121; (b) Y. Kita, R. Kavthe, H. Oda, K. Mashima, Angew. Chem. Int. Ed., 55 (2016) 1098-1101; (c) E.A. Standley, S.J. Smith, P. Müller, T.F. Jamison, Organometallics, 33 (2014) 2012-2018; (d) M. Shevlin, M.R. Friedfeld, H. Sheng, N.A. Pierson, J.M. Hoyt, L.-C. Campeau, P.J. Chirik, J. Am. Chem. Soc., 138 (2016) 35623569.

[7] X. Wu, Y. Zhao, H. Ge, J. Am. Chem. Soc., 136 (2014) 1789-1792.

[8] (a) X. Hong, Y. Liang, K.N. Houk, J. Am. Chem. Soc., 136 (2014) 2017-2025; (b) A. Arévalo, A. Tlahuext-Aca, M. Flores-Alamo, J.J. García, J. Am. Chem. Soc., 136 (2014) 4634-4639; (c) L. Gan, T.L. Groy, P. Tarakeshwar, S.K.S. Mazinani, J. Shearer, V. Mujica, A.K. Jones, J. Am. Chem. Soc., 137 (2015) 1109-1115; (d) R.C. Cammarota, C.C. Lu, J. Am. Chem. Soc., 137 (2015) 12486-12489; (e) A. Kruckenberg, H. Wadepohl, L.H. Gade, Organometallics, 32 (2013) 5153-5170; (f) B.R. Galan, E.S. Wiedner, M.L. Helm, J.C. Linehan, A.M. Appel, Organometallics, 33 (2014) 2287-2294; (g) A. Ghisolfi, F. Condello, C. Fliedel, V. Rosa, P. Braunstein, Organometallics, 34 (2015) 2255-2260. 
[9] (a) P.N. Plessow, L. Weigel, R. Lindner, A. Schäfer, F. Rominger, M. Limbach, P. Hofmann, Organometallics, 32 (2013) 3327-3338; (b) R. Fischer, J. Langer, A. Malassa, D.

Walther, H. Görls, G. Vaughn, Chem. Commun., (2006) 2510-2512; (c) L. Xue, M.S.G. Ahlquist, Inorg. Chem., 53 (2014) 3281-3289; (d) R. Beck, M. Shoshani, J.

Krasinkiewicz, J.A. Hatnean, S.A. Johnson, Dalton Trans., 42 (2013) 1461-1475; (e) P.N. Plessow, A. Schäfer, M. Limbach, P. Hofmann, Organometallics, 33 (2014) 3657-3668;

(f) L. González-Sebastián, M. Flores-Alamo, J.J. García, Organometallics, 34 (2015) 763-769.

[10] (a) A.M. Appel, J.E. Bercaw, A.B. Bocarsly, H. Dobbek, D.L. Dubois, M. Dupuis, J.G. Ferry, E. Fujita, R. Hille, P.J.A. Kenis, C.A. Kerfeld, R.H. Morris, C.H.F. Peden, A.R. Portis, S.W. Ragsdale, T.B. Rauchfuss, J.N.H. Reek, L.C. Seefeldt, R.K. Thauer, G.L. Waldrop, Chem. Rev., 113 (2013) 6621-6658; (b) Z. Yuan, M.R. Eden, R. Gani, Ind. Eng. Chem. Res., 55 (2016) 3383-3419; (c) P. Kang, Z. Chen, M. Brookhart, T.J. Meyer, Top. Catal., 58 (2015) 30-45; (d) G. Neri, I.M. Aldous, J.J. Walsh, L.J. Hardwick, A.J. Cowan, Chem. Sci., 7 (2016) 1521-1526; (e) Q. Liu, L. Wu, R. Jackstell, M. Beller, Nature communications, 6 (2015) 5933; (f) G.A. Olah, G.K. Prakash, A. Goeppert, J. Am. Chem. Soc., 133 (2011) 12881-12898; (g) R. Kortlever, J. Shen, K.J.P. Schouten, F. Calle-Vallejo, M.T.M. Koper, J. Phys. Chem. Lett., 6 (2015) 4073-4082; (h) S. Sato, T. Arai, T. Morikawa, Inorg. Chem., 54 (2015) 5105-5113; (i) G. Sahara, O. Ishitani, Inorg. Chem., 54 (2015) 5096-5104; (j) D.L. Dubois, Inorg. Chem., 53 (2014) 3935-3960; (k) M. Mikkelsen, M. Jørgensen, F. Krebs, Energy Environ. Sci., 3 (2010) 43-81; (1) D. Pletcher, Electrochem. Commun., 61 (2015) 97-101; (m) J. Qiao, Y. Liu, F. Hong, J. Zhang, Chem. Soc. Rev., 43 (2014) 631-675; (n) C. Costentin, M. Robert, J.-M. Savéant, Chem. Soc. Rev., 42 (2013) 2423-2436; (o) M. Aresta, A. Dibenedetto, A. Angelini, Chem. Rev., 114 (2014) 1709-1742; (p) L.J. Murphy, K.N. Robertson, R.A. Kemp, H.M. Tuononen, J.A.C. Clyburne, Chem. Commun., 51 (2015) 3942-3956; (q) U.-P. Apfel, W. Weigand, Angew. Chem. Int. Ed., 50 (2011) 4262-4264.

[11] C.R. Groom, F.H. Allen, Angew. Chem. Int. Ed., 53 (2014) 662-671.

[12] A. Grabulosa, S. Doran, G. Brandariz, G. Muller, J. Benet-Buchholz, A. Riera, X. Verdaguer, Organometallics, 33 (2014) 692-701.

[13] (a) V.V. Sushev, A.N. Kornev, Y.V. Fedotova, Y.A. Kursky, T.G. Mushtina, G.A. Abakumov, L.N. Zakharov, A.L. Rheingold, J. Organomet. Chem., 676 (2003) 89-93; (b) V.V. Sushev, A.N. Kornev, Y.A. Kurskii, O.V. Kuznetsova, G.K. Fukin, Y.H. Budnikova, G.A. Abakumov, J. Organomet. Chem., 69 (2005) 1814-1821.

[14] D.A. Dickie, R.A. Kemp, Acta Crystallogr. Sect. E: Struct. Rep. Online, E64 (2008) o1449.

[15] D.A. Dickie, M.V. Parkes, R.A. Kemp, Angew. Chem. Int. Ed., 47 (2008) 9955-9957.

[16] D.A. Dickie, R.A. Kemp, Organometallics, 33 (2014) 6511-6518.

[17] D.A. Dickie, E.N. Coker, R.A. Kemp, Inorg. Chem., 50 (2011) 11288-11290.

[18] D.A. Dickie, M.T. Barker, M.A. Land, K.E. Hughes, J.A.C. Clyburne, R.A. Kemp, Inorg. Chem., 54 (2015) 11121-11126.

[19] J.S. Ritch, T. Chivers, K. Ahmad, M. Afzaal, P. O'Brien, Inorg. Chem., 49 (2010) 11981205.

[20] Bruker AXS, Inc., Madison, Wisconsin, USA (2015).

[21] G. Gritzner, J. Kůta, Pure Appl. Chem., 56 (1984) 461-466.

[22] R.R. Gagné, C.A. Koval, G.C. Lisensky, Inorg. Chem., 19 (1980) 2854-2855. 
[23] B.M. Barry, D.A. Dickie, L.J. Murphy, J. Clyburne, R.A. Kemp, Inorg. Chem., 52 (2013) 8312-8314.

[24] P. Stoessel, D. Joosten, E. Breuning, H. Yersin, U. Monkowius, in, Merck Patent GmbH, Germany . 2010, pp. 80pp.

[25] A.M.Z. Slawin, M.B. Smith, J.D. Woollins, J. Chem. Soc., Dalton Trans., (1997) 18771881.

[26] C.J. Pouchert, The Aldrich Library of Infrared Spectra. 3rd Ed, Aldrich Chem. Co., 1981.

[27] C.J. Miller, U. Chadha, J.R. Ulibarri-Sanchez, D.A. Dickie, R.A. Kemp, Polyhedron, 114 (2016) 351-359.

[28] J. March, Advanced Organic Chemistry: Reactions, Mechanisms and Structure, 4th ed., Wiley \& Sons, New York, 1992.

[29] R. Holtzwart, J. Prakt. Chem., 39 (1889) 230-245.

[30] K.O. Christe, W.W. Wilson, R.D. Wilson, R. Bau, J.-a. Feng, J. Am. Chem. Soc., 112 (1990) 7619-7625.

[31] A.L. Rheingold, M. Gembicky, CCDC 1428277: Private communication to the Cambridge Structural Database (2015), DOI: 10.5517/cc1jy7g5.

[32] E. Simón-Manso, C.P. Kubiak, Organometallics, 24 (2005) 96-102.

[33] R.J. Enemaerke, J. Larsen, T. Skrydstrup, K. Daasbjerg, Organometallics, 23 (2004) 18661874.

[34] in: In practical terms, electrochemical reversibility (also termed Nernstian behavior) refers to the speed of charge-transfer in a redox reaction, whereas chemical reversibility refers to follow-up reactions that accompany the charge-transfer process. For an introductory discussion of these terms, see Bard, A. J.; Faulkner, L. N., Electrochemical Methods, John Wiley \& Sons, New York, 2001, 2nd Ed., pp 35-38 and pp 44-49).

[35] R.J. Haines, R.E. Wittrig, C.P. Kubiak, Inorg. Chem., 33 (1994) 4723-4728. 
Graphical abstract - synopsis

\section{Graphical Abstract Synopsis}

Bis(diisopropylphosphino)amine (HL) reacts with $\mathrm{NiX}_{2}(\mathrm{X}=\mathrm{Br}, \mathrm{I})$ and $\mathrm{NiX}_{2} \bullet 6 \mathrm{H}_{2} \mathrm{O}(\mathrm{X}=\mathrm{Cl}$, $\left.\mathrm{BF}_{4}, \mathrm{NO}_{3}, \mathrm{ClO}_{4}\right)$ to form $\mathrm{P}, \mathrm{P}$-chelated complexes $(\mathrm{HL}) \mathrm{NiX}_{2}(\mathrm{X}=\mathrm{Cl}, \mathrm{Br}, \mathrm{I})$ and $\left[(\mathrm{HL})_{2} \mathrm{Ni}\right] \mathrm{X} 2(\mathrm{X}$

$\left.=\mathrm{BF}_{4}, \mathrm{NO}_{3}, \mathrm{ClO}_{4}\right)$, each of which was crystallographically characterized. Electrocatalytic reduction of $\mathrm{CO}_{2}$ was observed for each of the latter set of compounds. 

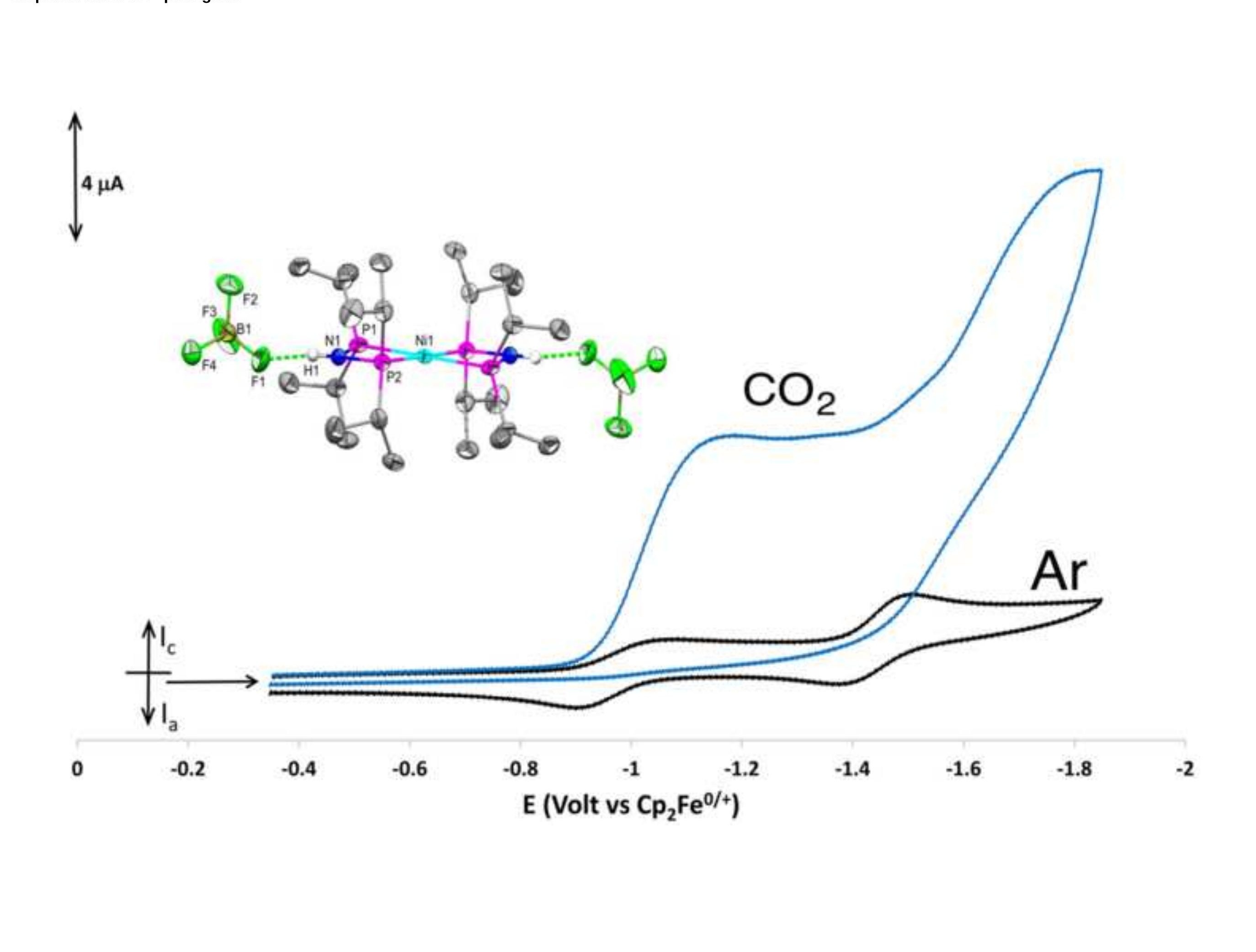

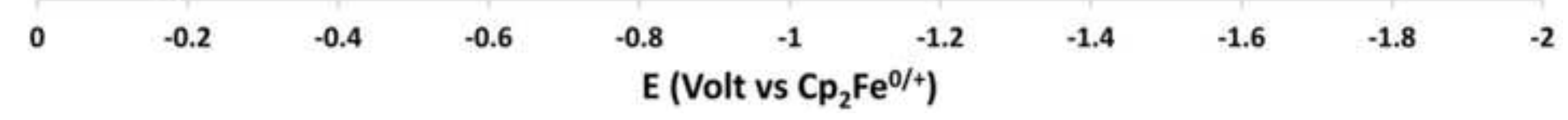

-

(5-

(

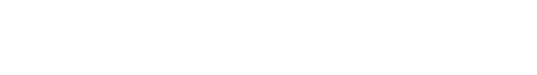
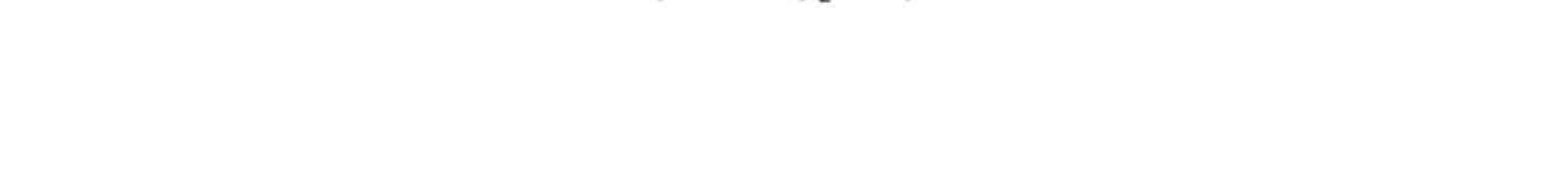